УДК 94(100)"1914/1918"; 32(497)"190/191"

Dr Mile BJELAJAC

\title{
NOVI (STARI) ZAPLETI OKO UZROKA PRVOG SVETSKOG RATA PRED OBELEŽAVANJE 100. GODIŠNJICE*
}

\begin{abstract}
APSTRAKT: Što se više bliži 100. godišnjica od izbijanja Prvog svetskog rata, to su sve češći novi naslovi istorijskih radova kojima izdavači žele da je obeleže. Za razliku od ranijih godišnjica, ovu karakteriše pokušaj da se reinterpretira uloga Balkana, posebno Srbije u ključnim razlozima izbijanja rata. Deo produkcije karakteriše pokušaj namernog sklanjanja u stranu već utvrđenih činjenica o uticaju međuratne politike nemačkih vlada na skidanje odgovornosti za rat po svaku cenu. Oživljavanje tog trenda sa pečatom postmoderne istoriografije predstavlja izazov za praćenje produkcije $i$ njeno kritičko preispitivanje. Ovaj članak predstavlja prilog u tom pravcu.
\end{abstract}

Ključne reči: uzroci Prvog svetskog rata, Sarajevo 1914, Srbija, Kristofer Klark

Rasprave oko uzroka, povoda i krivice za Prvi svetski rat imaju svoju stručnu, ideološku i političku dimenziju. Kao i mnoga druga pitanja od epohalnog značaja, delile su i još uvek dele istoričare. Rasprave odražavaju političku zainteresovanost i provociraju tradicionalne tokove društvene (istorijske) svesti, ponekad bolno pogađaju u središte kulturnih identiteta. Politička instrumentalizacija ovog pitanja započeta je još tokom Prvog svetskog rata, a svoju posebnu dimenziju dobila je unošenjem specifičnih članova o "krivici za rat" u mirovne ugovore

\footnotetext{
* Rad je rezultat rada na projektu Tradicija i transformacija - istorijsko nasleđe $i$ nacionalni identiteti u Srbiji u 20. veku (№ 47019), koji finansira Ministarstvo prosvete, nauke i tehnološkog razvoja Republike Srbije.
} 
u Versaju (čl. 231) i San Žermenu (čl. 177). ${ }^{1}$ Vreme između dva svetska rata imalo je po ovom pitanju svoja obeležja, kao što će nova učitavanja slediti tokom hladnog rata, kada se težilo homogenizaciji zapadnog bloka (NATO) sastavljenog od nekadašnjih protivnika. Poseban pravac razvoja ove teme odvijao se na tragu preispitivanja nemačke odgovornosti za Drugi svetski rat. Tradicionalna nemačka "škola prikrivanja” suočila se sa novim hrabrim trendovima koji su doveli do nekih od najpoznatijih kontroverzi („Fišerova kontroverza"). Sve ovo ne bi bilo moguće bez novih prodora u nepoznatu ili namerno "prikrivanu" građu.

Nov pristup „Balkanu” 90-ih, posebno interpretacije uloge srpskog faktora, ponovo nas je vratio u neka vremena kada se više raspravljalo o "krivici za rat" nego o istorijskom sledu stvari, dubokim korenima globalnih konfrontacija koje su se u jednom istorijskom momentu pretvorile u veliki rat. Najpregnantniji izraz tog novog političkog prilagođavanja predstavlja govor američkog predsednika Klintona u kome je njegov sastavljač napisao da su dva svetska rata započela na Balkanu. Ponovo se na kraju 20. veka povampirila stara austrougarska floskula o "necivilizovanom" Balkanu gde jedna "civilizovana" velika sila treba da zavede red. Ako stanje i nije bilo toliko "necivilizovano", trebalo ga je takvim predstaviti. Jednako tako su obnovljene sve predrasude rasističkih korena prema Balkanu koje su kultivisane u samoj Nemačkoj. ${ }^{2}$

Različit nivo diskusija vođenih prethodne godine u svetu povodom 100. godišnjice balkanskih ratova ukazuje na moguće pravce rasprava povodom izbijanja Prvog svetskog rata. Posebno je prisutno jedno potpuno neistorično razumevanje nacionalizama, ideja slobode, ideja jednakosti krajem 19. i početkom 20. veka. Odriče se tradiciji borbe

1 Komisija za utvrđivanje ratne krivice pod rukovostvom Amerikanca Roberta Lensinga završila je izveštaj 29. marta 1919. sa zaključkom: „Rat je isplaniran od strane Centralnih sila kao i od njihovih saveznica Bugarske i Turske i rezultat je delovanja ostvarenih s predumišljajem i u nameri da se isti učini neizbežnim. U saglasnosti sa Austro-Ugarskom Nemačka je svesno radila na tome da na stranu gurne brojne posredničke predloge Antante i osujeti njena ponovljena nastojanja da se rat spreči." Po Lensingu pokretači osvajačkog rata morali su biti žigosani pred istorijom. (Велибор Буха, Србија у немачком и аустријском тумачењу кривице за Први светски рат 1919-1941, (магистарски рад), Београд, 2010, стр. 14-15).

2 Momčilo Selesković, Srbija u nemačkom javnom mnjenju 1914-1918, Sorbona, 1919 (Beograd, 1996); Milorad Ekmečić, Beleška o ulozi rasizma u određivanju nemačkih ratnih ciljeva 1914-1918, u: M. Ekmečić, Ogledi iz istorije, drugo izdanje, Službeni list SRJ, Beograd, 2002, str. 273-284; Милан Ристовић, Црни Петар и балкански разбојници, Балкан и Србија у немачким сатиричним часописима (1903-1918), Уди-Чигоја штампа, Београд, 2011. 
za slobodu legitimitet, posebno kada se ta borba odvija na teritorijama od posebnog interesa za nekadašnje imperije. ${ }^{3}$ Namerno se previđa da je želja za slobodom, npr. u Bosni i Hercegovini bila izražena ne samo tokom ustanka 1875-1878. već i kasnije pod austrougarskom okupacijom. Zaboravlja se da je prvi veliki egzodus muslimana krenuo na istok upravo sa prostora $\mathrm{BiH}$, sa teritorije gde je uz borbu nametnuta okupacija a kasnije i puna vlast. Zaboravlja se ogorčenost srpskog i muslimanskog stanovništva povodom aneksije 1908. Volšebno, egzodus sa Balkana "počinje" 1912, pa čak i "genocid". Današnje težnje za "humanim" formama globalizacije protežu se na oslikavanje nekadašnjih imperija kao tolerantnih verskih i multietničkih tvorevina. ${ }^{4}$ Da li bi danas Italijani, Mađari, Česi, Slovaci, Poljaci ili Rumuni pristali da se čitava njihova istorija 19. veka, pa i ona iz Prvog svetskog rata prevrednuje zarad potreba sila koje su dva svetska rata skinula sa pozornice? Trendovima istorijskog revizionizma deluje nesuvislo pominjanje svakog istorijskog fakta koji "odstupa" od nove političke korektnosti. Tako je za neke učesnike rasprava o balkanskim ratovima "sumnjivo" pisanje splitske Slobode, organa Hrvatske pučke napredne stranke, koja je 18. avgusta 1912. na naslovnoj strani, pod naslovom "U Hrvatskoj dižu se vješala..." donela vest o presudama Luki Jukiću (atentatoru na bana Cuvaja), Đuri Cvijiću, Augustu Cesarecu, Franji

3 Prof. istorije Snider sa Univerziteta Jejl (Yale University) je jedan od primera (Timothy Snyder, "Hitler's Logical Holocaust", The New York Review of Books, (Dec. 20, 2012), Internet http://www.nybooks.com/articles/archives/ 2012/dec/20 /hitlerslogical-holocaust/. Po njemu, osim nacionalizama koji razoriše Tursku, "postojali su elementi unutar srpske vlade koji su pokušavali da oduzmu deo teritorija od Austrije kao što su prethodno uradili i sa Osmanlijama". Rusi i Srbi su krivi za mnoga zla koja civilizovani svet ne bi mogao počiniti. Kao i Kaplan, misli da su balkanski nacionalizmi uticali na modeliranje Hitlerovog mišljenja i programa.

4 M. Hakan Yavuz, P. Sluglett (eds), War \& Diplomacy. The Russo-Turkish War of 1877-1878, Utah University Press 2010, „Introduction - Laying Foundations for Future Instability", str. 1, 2, 4. i tekst na koricama. Dva priređivača pišu da zbornik "argues that the key events that portended the beginning of the end of the multiethnic Ottoman Empire were the Russo-Turkish War of 1877-1878 and the Treaty of Berlin. The essays in this volume analyze how the war and the treaty permanently transformed the political landscape both in the Balkans and Caucasus. The Treaty marked the end of Ottoman hegemony in the Balkans... By introducing the unitary nation state as the new organizing concept, the treaty planted the seeds of future conflict, from the Balkan Wars of 1912-1913 and the First World War to recent civil wars and ethnic cleansing in former Yugoslavia. The magnitude of the defeat ... and territorial loses that followed proved fatal to the project of Muslim liberal reform and modernization that the Ottoman state had launched in the middle of the nineteenth century." U predgovoru (str. 2) može da se pročita i sledeća tvrdnja: "Montenegro obtained most of the Albanian-inhabited territories of Nikšić, Podgorica and Bar". Ovo viđenje preporučuju: Kemal Silay, Indiana University Bloomington, i Ali Yayciogly, Stanford University. Slične stavove u Nemačkoj zastupa prof. Fikret Adanir. 
Neidhardu i drugovima od 12. avgusta na sudu u Zagrebu. Članak, ili tačnije plakat, završava usklikom: „Nek se lije krv, jer se samo krvlju natapa stablo Slobode. Nek živi ujedinjenje i oslobodjenje Jugoslovena: Hrvata, Srba i Slovenaca". Bilo je to dva meseca pre izbijanja rata koji će egzaltirati duhove Slovena širom Monarhije. ${ }^{5}$

Sjedinjući u vlastitom iskustvu bavljenje temama sa početka veka i njegovog kraja (jugoslovenska kriza i razbijanje SFRJ), smatramo da bi svakom istoričaru bilo od pomoći da zna mehanizme državnog uticaja na istoričare (domaće i strane), na selektivno objavljivanje dokumenata, akcije njihovog prikrivanja, pa i falsifikovanja. Konkretan primer o utvrđivanju odgovornosti za Prvi svetski rat belodano pokazuje kako se u državnom interesu vrši lobiranje, kako se pridobijaju i podržavaju „istomišljenici", a kako se organizuju hajke i progoni "oponenata” među istoričarima. Na kraju, istoričari moraju biti obavešteni o podelama u svom esnafu pre nego započnu citiranje ili apsolutno oslanjanje na pojedine pravce mišljenja i interpretacije.

\section{Da li je Srbija 1914. želela krizu i rat?}

Unutar same srpske istoriografije nisu posle radova Andreja Mitrovića otvarana pitanja srazmere povoda i uzroka Prvog svetskog rata i sledstveno pitanje uloge srpske vlade i faktora iz same Srbije u pripremi Sarajevskog atentata 1914 . godine. ${ }^{6}$ Kapitalni rezultati profesora Mitrovića nisu samo plod oslanjanja na radove Fišera (Fritz Fischer) i Emanuela Gajsa (Imanuel Geiss) i mnogih drugih nemačkih i austrijskih naučnika već su se temeljili i na vlastitim istraživanjima u bečkim i nemačkim arhivima, na državnim i ličnim fondovima, ali i na građi koja se čuva u srpskim i svetskim arhivima. Mitrovićevi i radovi Milorada Ekmečića stavili su u bolji istorijski kontekst nekadašnja saznanja pisaca i savremenika o sarajevskom atentatu. ${ }^{7}$ Značajno su dopunili i prevazišli nekada svetski poznat, veliki rad Vladimira Dedijera

5 Josip Horvat, Pobuna omladine 1911-1914, (priredio Branko Matan), SKD Prosvjeta, Gordogan, Zagreb, 2006, str. 172.

6 Andrej Mitrović, Prodor na Balkan, Srbija u planovima Austro-Ugarske i Nemačke 1908-1918, Nolit, Beograd 1981, (drugo izdanje 2011); Исти, Србија у Првом светском рату, СК3, Београд, 1984 (eng. izdanje: Serbia's Great War 1914-1918, Hurst \& Co., London, 2007); videti takođe: isti, „Fric Fišer ili nemačko suočavanje sa istorijom", uvodna studija u: Fric Fišer, Savez elita, Nolit, Beograd, 1985, str. 9-53.

7 Милорад Екмечић, Стварање Југославије 1790-1918, Београд, 1989; исти, Ратни циљеви Србије 1914. године, 1973 (1990). Posebno je značajan za ovu temu predgovor drugom izdanju. 
Sarajevo $1914 .{ }^{8}$ Širokoj javnosti je, konačno, 1992. godine postala dostupna knjiga Vladimira Ćorovića koja je 1936. bila zabranjena. ${ }^{9}$ Za žaliti je što je ostao nedovršen projekat izdavanja srpske diplomatske građe. ${ }^{10}$ Pored nekoliko članaka, ${ }^{11}$ na Odelenju za istoriju u Beogradu odbranjen je tek jedan magistarski rad 2010.12

Za temu je od značaja pomenuti i radove Đorđa Stankovića o Nikoli Pašiću, posebno ona svedočanstva o željama srpskog državnika za trajnim poboljšanjem odnosa sa Austro-Ugarskom posle balkanskih ratova. Ovde je od naročitog interesa skupštinski ekspoze Nikole Pašića 16/29. oktobra 1913. godine. Zahvaljući se pojedinačno evropskim državama za podršku Srbiji i očuvanju mira, istakao je dve bitne stvari. Prvo, da je srpskom narodu posle sjajnih pobeda, kao i balkanskim državama, potreban mir i period mirnog razvoja po svim granama: "Kraljevska Srpska vlada uverena je, da je potreban narodu srpskom dugi period mira radi kultivisanja dobivenih pokrajina i svestranog razvijanja, i s toga je zadahnuta težnjom da sa svima susedima i ostalim državama živi u miru i prijateljstvu, i da uklanja ove smetnje, koje bi slabile politiku mira i dobrog susedstva." 13

8 V. Dedijer, Sarajevo 1914, Beograd, 1966 (1979), (eng. izdanje: The Road to Sarajevo, London, 1967; franc. izdanje: Sur la route de Sarajevo, Gallimard, Paris, 1969).

9 Владимир Ћоровић, Односи између Србије и Аустро-Угарске у XX веку, Библиотека града Београда, 1992.

10 Документа о спољној политици Краљевине Србије 1903-1914, САНУ, Београд, 1980 (1981, 1982, 1984, 1986, 2004, 2006, 2008, 2009). - Edicija je planirana u 14 tomova, a jedan broj njih u više knjiga, odnosno tematskih "dodataka". Objavljeni su tomovi I, II, V, VI, VII, svaki u više knjiga. Od dodataka spomenimo uz knjigu 2. tri dodatka sa građom Српска народна одбрана 1906, Организација српска одбрана 1907, 1903-1914. Objavljene su i Дипломатска преписка Краљевине Србије, књига I (1. јануар 1902 - 1. јун 1903), приредио Владимир Ћоровић, Државна штампарија, Београд, 1933.

11 Čedomir Antić, "Crisis and Armament, Economic Relations between Great Britain and Serbia 1910-1912", Balcanica, XXXVI, 2005, str. 151-161; Vojislav Pavlović, "La troisième guerre balkanique. La France et les tentatives des Alliés de créer une nouvelle alliance balkanique 1914-1915", Balcanica, XXXVIII, 2007; Александар Растовић, "Енглези и умешаност Србије у Сарајевски атентат”, Зборник за историју БиХ, 5 (2008), САНУ, стр. 261-271.

12 Велибор Буха, Србија у немачком и аустријском тумачењу кривице за Први светски рат 1919-1941, Београд, 2010. Rad je odbranjen pred komisijom: Milan Ristović (mentor), Ljubinka Trgovčević, Dubravka Stojanović i Mile Bjelajac. Srpski istoričar Čedomir Antić je nešto ranije odbranio MA tezu, "Sir Ralph Paget and British Policy towards Serbia from 1910 to 1913" (Bristol, 2002). Objavljena je kao knjiga u izdanju Balkanološkog instituta: Ralph Paget, A Diplomat in Serbia, Belgrade, 2006.

13 Ђ. Станковић, Сто говора Николе Пашића, Вештина говорништва државника, РАД, Београд, 2007, Књ. 1, стр. 359. 
Pašić je istakao da je, uprkos izraženoj spremnosti da postupa po željama velikih sila u pitanju Albanije i priznavanja granice utvrđene u Londonu, Srbija bila iznenađena ultimatumom Austro-Ugarske da se srpska vojska povuče u roku od osam dana. Od sila je tada zatraženo da one garantuju da nova država neće biti izvor nemira i napada na prava drugih. „Mi možemo samo duboko žaliti što se pored naše najbolje volje da povratimo poverenje u dobro raspoloženje između Srbije i Austro-Ugarske, uvek desi po neki slučaj neobjašnjiv koji kvari i ometa dobro raspoloženje za rešavanje pitanja, korisnih po obe strane."14

Ovo javno svedočenje u srpskoj skupštini kao da dobija dragocenu potvrdu u nedavno prezentovanim istraživanjima istoričarabalkanologa iz Brna Vaclava Štjepaneka. On je saopštio da je u arhivi austrijskog ministarstva spoljnih poslova otkrio dokument s kraja 1912. o dosad malo poznatoj ponudi Beču tadašnjeg predsednika vlade Srbije Nikole Pašića. Srpski predsednik vlade obratio se preko posrednika austrougarskom ministru spoljnih poslova Bertholdu. Austrougarskoj je predlagao - i nudio da se radi potvrde prestiža Habzburške monarhije to učini ako treba i javno u formi molbe - kompletni, može se reći, istorijski sporazum o svim spornim pitanjima i neusaglašenim interesima dve države, kako jedna drugoj ne bi stajale na putu i kako bi se sprečio rat. Štjepanek je objasnio da je upravo ovo otkriće potvrdilo autentičnost Masarikovih svedočenja za koja su istoričari znali. Ukratko saznajemo da je postojala tajna ponuda Pašića koju je poslao preko Masarika, tada uglednog češkog profesora, političara i poslanika u austrijskom parlamentu, koji je u decembru 1912. boravio u Beogradu, u jeku Prvog balkanskog rata kada se krojila nova politička mapa Balkana. "Odnosi između ove dvojice političara", kako je izneo Štjepanek, ,'nikad nisu bili vreli'. Zastupali su različita politička uverenja i njihova saradnja je bila više stvar racionalnog uvažavanja nego uzajamne naklonosti (...) Kao dokaz svoje miroljubivosti, (Pašić - M. B.) je iskazao spremnost da dođe u Beč i da se pokloni Bertholdu kako bi se time utolila bečka glad za prestižom. Plan sam preneo Bertholdu (...) ali on te stvari nije razumeo i nije se privoleo miru." Masarik se potom žalio moćnom ministru Bilinskom (ministar finansija, zadužen i za Bosnu i Hercegovinu), Barenrajtereru i drugim ministrima, oni su svi bili očajni, pokušali su da isprave grešku Bertholda, ali im nije uspelo. "Incident s Berhtoldom verovatno je Masarika utvrdio u očekivanju

14 Isto, str. 360-361. (Ovaj ekspoze je štampan u posebnoj brošuri koja je imala političku i diplomatsku važnost). Isti tekst objavljen je i u: Дубравка Стојановић (приређивач), Никола Пашић у Народној скупштини, III, Београд, 1997, стр. 528-538. 
rata, pa ga kasnije nije napad na Srbiju ni iznenadio", ocenjuje Štjepanek. Saznajemo da je Masarik s Pašićem imao jedan zvaničan, dosta formalan susret, na kome se domaćin ponašao uzdržano. Na dan kad je trebalo da se vrati natrag, kratko pred polazak voza, ponovo je bio pozvan kod Pašića i tamo mu je ovaj rekao da hoće da mu kao privatnoj osobi poveri nešto što oficijelnim putem ne bi mogao poslati Beču. „Pašićeve predloge je Masarik Berhtoldu preneo detaljno, a Štjepanek ih je sumirao u nekoliko tačaka. Ukratko, Srbija želi da živi sa Austrijom u miru i prijateljstvu, pri čemu želi da sačuva svoju ekonomsku i političku nezavisnost. Srpska država je zainteresovana za razvoj žive trgovine s Dualnom monarhijom i nudi povoljne koncesije, od godine 1917. trgovinski režim sa ugrađenom klauzulom najvećih pogodnosti obezbediće Austriji prednost u odnosu na Nemačku. Srbija nudi i mogućnost korišćenja svojih postojećih železničkih pruga, kao i da se grade nove. Za sve to traži, radi obezbeđivanja svoje ekonomske nezavisnosti, jednu jadransku luku, do koje bi vodila pruga u uskom pojasu koji bi bio pod srpskim suverenitetom. Luka bi bila isključivo trgovinska i Kraljevina Srbija bi se obavezala da je neće koristiti kao ratnu i neće je davati za bazu drugih sila. U slučaju da Beč ne izađe u susret ovim zahtevima Srbije, ona će se morati mnogo tešnje povezati sa drugim balkanskim državama, a eventualno stvoriti carinsku uniju s Bugarskom."15

Podsetimo da je vlada krajem 1913. godine, želeći smirivanje situacije, zahtevala ukidanje službe "graničnih oficira". Oficiri, crnorukci, koji su pre ratova držali vezu sa Bosnom i Hercegovinom, razvijali tamo svoju obaveštajnu mrežu, sarađivali sa Narodnom odbranom, posredovali u dolasku dobrovoljaca na obuku i kasnije u rat, tada su bili povučeni sa granice i date su im druge trupne dužnosti u garnizonima u unutrašnjosti ili u novim oblastima. $U$ toj grupi će biti i nekoliko najistaknutijih koje je Austro-Ugarska prozivala na procesima u Sarajevu i Banjaluci. Fakat je da je to bio rad do septembra 1913.16 Euforija omladine i stanovništva izazvana pobedama u balkanskim ratovima, sećanje na 1908. i 1909. raspalili su nadanja u skoro oslobođenje. Istorija Mlade Bosne, spremnost njenih članova na žrtvovanje predstavljaju je kao autohtoni pokret. U njenom krilu rođena je ideja za

15 Milan Lazarević, „Pašić nudio nagodbu Beču, Zanimljivo otkriće češkog istoričara”, Danas, 30. 11. 2012. Istoričar John Zametica nam je skrenuo pažnju da je ta epizoda interpretirana i u: Hugo Hantsch, Leopold Graf Berchtold. Grandseigneur und Staatsmann (Verlag Styria, Graz, 1963), tom I, str. 369-373.

16 Чеда Поповић, "Сарајевски атентат и организација 'Уједињење или Смрт'", Nova Evropa, knj. XXV, br. 8, 26. jul 1932, str. 400-401. 
atentat kakav se ranije pripremao na cara i druge velikodostojnike. Oni koji su u trenutku rađanja ideje za takav čin bili van Sarajeva (Princip i Čabrinović) pozvani su da se pridruže. Rečima Borivoja Jevtića, člana organizacije, "on (atentat - M. B.) nije izliv jednog trenutka, nego delo dugo spremano, delo koje je pripravljao ceo jedan naraštaj, rešen da se za svoja ljudska i nacionalna prava bori na život i smrt sa neprijateljem". Potreba Srbije za predahom i oporavkom te dugim periodom mira nije se shvatala. ${ }^{17}$

Namere srpske vlade da se poboljšaju odnosi Srbije sa AustroUgarskom notira i otpravnik poslova ruskog poslanstva u Beogradu Vasilij Štrandman. Kako je Monarhija koristila svako pitanje da zategne odnose, on navodi da je srpska vlada izrazila spremnost da joj pruži koncesije u pogledu rešenja pitanja železnica u novim oblastima. U tom cilju su u Beograd stigli predstavnici bečke železničke direkcije. Atentat ih je prekinuo u sred posla. ${ }^{18}$

Obaveštene da Austro-Ugarska vrlo nepovoljno gleda na pregovore Srbije i Crne Gore o realnoj uniji, obe srpske vlade su privremeno suspendovale ove pregovore. Ovo je, posle uznemiravajućih informacija iz Berlina i Beča, ruski ministar Sazonov, preko Hartviga, tražio od srpske vlade. ${ }^{19}$

Iz razgovora koje je Štrandman imao sa prestolonaslednikom Aleksandrom i premijerom Pašićem vidi se da su ovi odgovorni faktori bili svesni srpske nespremnosti za nove krize, a pogotovo za rat. Njihov najjači argument je bio vojna nespremnost koja se ne bi mogla prevladati ni u tri sledeće godine zbog istrošenosti u balkanskim ratovima. U poslednjem šifrovanom telegramu Sazonovu iz Beograda 23. jula 1914. otpravnik poslova Štrandman je široko izneo detaljne poglede Pašića na situaciju. Nedvosmisleno je da je Srbija bacala pogled na oslobođenje i ujedinjenje sa braćom u Bosni, ali do pogodne međunarodne konjukture je bilo daleko. Radila je na političkoj konsolidaciji sa Rumunijom, Crnom Gorom i Grčkom, pa u perspektivi i sa Bugarskom, kako bi ojačala pozicije. Tu su bili problemi i unutrašnje

17 Боривоје Јефтић, Сарајевски атентат, сећања и утисци, Сарајево, 1923; Tartalja Oskar, Veleizdajnik - Moje uspomene iz borbe protiv Crnožutog Orla, Split, 1928; Veselin Masleša, Mlada Bosna, Beograd, 1945; Драго Љубибратић, Гаврило Принцип, Београд, 1959; Исти, Владимир Гаћиновић, Нолит, Београд, 1961; V. Dedijer, Sarajevo 1914, Beograd, 1966; Josip Horvat, Pobuna omladine 1911-1914, (priredio Branko Matan), SKD Prosvjeta, Gordogan, Zagreb, 2006.

18 Василиј Штрандман, Балканске успомене, књига I, део 1-2 (превео са руског Јован Качачки), Жагор, Београд, 2009, стр. 266.

19 Isto, str. 264. 
prirode koji su zahtevali vreme. Samo za opremanje vojske smatralo se da su potrebne tri godine, kao i za gradnju mosta preko Dunava koji bi Srbiju povezao sa Rumunijom. Veći broj godina bio je potreban za gradnju pruga na jugu i kroz Sandžak i pouzdanih i brzih komunikacija periferije sa centrom. U zaključku Štrandman navodi:

„Iz svega iznetog nije teško zaključiti da se nastupanje događaja, koji bi sada i u neposrednoj budućnosti mogli do krajnosti da zaoštre austrijsko-srpske odnose, u Beogradu smatra ne samo nepoželjnim, nego i opasnim po opstanak same Kraljevine. U takvu vrstu događaja treba uvrstiti ubistvo Prestolonaslednika (...) ubistvo koje je Srbiji pomrsilo sve planove i dovelo na dnevni red pitanje vojnog sukoba sa velikom silom u najnepovoljnijem trenutku po nju (kurziv, M. B.). Stoga je razumljiva zebnja koja je zahvatila ne samo srpsku vladu, nego još više Kraljevića Regenta koji je, potpuno svestan neopremljenosti srpske vojske, smatrao da bi sa austrijske tačke gledišta bila 'velika glupost' ne iskoristiti nastale okolnosti kako bi se Srbiji predočili neprihvatljivi zahtevi i time izazvao oružani konflikt (...) Uzimajući u obzir sve gore navadeno, sa sigurnošću se može kazati da će Kraljevska vlada povodom očekivanog austrougarskog nastupa u Beogradu izaći u susret svim mogućim zahtevima koji su ma i najmanje u skladu sa dostojanstvom samostalne države."20

Otpravnik poslova Štrandman još jednom svedoči o naporima srpskog poslanika u Beču Jovana Jovanovića da preko austrougarske vlade utiče da se odgodi poseta Ferdinanda Bosni: "U Beogradu, na stanici nas je sačekao L. S. Zarin i na brzinu me obavestio o uznemirenosti koja vlada u gradu, kao i o glasinama koje se šire o tome da Beč optužuje srpsku vladu za vezu sa sarajevskim događajem i traži da Srbija zbog toga bude primereno kažnjena. Skrenuo mi je pažnju na to da je srpski poslanik u Beču Jovan Jovanović upozoravao austrougarskog ministra finansija Bilinskog, u čijoj nadležnosti su bili bosanski poslovi, na opasnost kojoj se može izložiti nadvojvoda Franc Ferdinand na manevrima zakazanim za mesec juni. Jovanović je ispoljio ličnu inicijativu, poznavajući raspoloženje u Bosni. Ali naš poslanik (Hartvig - M. B.) kako mi je Zarin kazao, ne menja svoje planove."21

\footnotetext{
20 Isto, str. 290.

21 Isto, str. 260.
} 


\section{Da li je F. Ferdinand viđen kao pretnja miru samo kod Srba?}

Srpski organi su pravilno cenili ili naslućivali da Austro-Ugarska ima daleksožne planove za prekomponovanje Balkana, podređivanje Srbije, a tokom balkanskih ratova i nameru da zgodnim povodom izvrši vojnu intervenciju i oduzme Srbiji postignuća. U skladu sa ovim procenama bio je saobražen ratni plan koji je namenio Ibarskoj vojsci generala Živkovića zaštitnu funkciju za slučaj austrougarske intervencije dok budu tekle glavne operacije. Obaveštajno odeljenje srpskog generalštaba primilo je u jesen 1912. godine od italijanskog glavnog generalštaba, a preko pukovnika Negrija, tačne podatke o austrougarskom planu prema Srbiji. Italija, koja je bila saveznica Austro-Ugarske, iskusila je njeno preteće držanje tokom italijansko-turskog rata 1911-12. Slične su bile i "procene" generala Fičeva. Bilo je i drugih znakova koji su ukazivali na udar iz Bosne i preko Save u Mačvu, posebno razvoj pruga ka toj granici i špijunsko izviđanje nastupajućih pravaca. Takođe generalštabna putovanja austrougarskog generalštaba obavljana su u Bosni i prema Drini. Kada je Obaveštajno odeljenje srpskog generalštaba napravilo skicu austrougarske špijunaže prema Srbiji za period 1908-1910. iz nje se videlo da je glavni pravac izviđanja prema Užicu i Valjevu, a ne moravski pravac. ${ }^{22}$

Pukovnik Dragutin Dimitrijević Apis je posle balkanskih ratova postao načelnik Obaveštajnog odeljenja i po prirodi svoje službe morao je pažljivo da ceni obaveštenja o namerama Austro-Ugarske. Sva ondašnja obaveštenja, kako ona istinita i tačna tako i ona netačna, ponekad tendenciozna, sugerisala su isto: zvanična Austrija ima ozbiljnu nameru i sprema se da napadne, po svaku cenu na Srbiju i da nađe ma kakav pretekst za rat, budući da je Srbija tada bila najslabija. Politički događaji, o čemu je štampa pisala, sugerisali su isti zaključak. Najava da će se u Bosni održati veliki manevri, piše pukovnik Čeda Popović, kao i najava da će njima rukovoditi sam nadvojvoda Ferdinand ozbiljno je uzbudila Apisa. Omladina u Bosni je, s druge strane, doživela to kao vrhunsku provokaciju. $U$ to vreme gotovo celokupna kadrovska vojska je bila u novooslobođenim oblastima. Akcije Austro-Ugarske na podbunjivanju Albanaca bile su dobro poznate Apisu. Dok je vojni izaslanik Srbije u Beču izveštavao da je sve podređeno skoroj okupaciji

22 M. Bjelajac, P. Trifunović, Između vojske i politike. Biografija generala Dušana Trifunovića 1880-1942, Beograd, 1997, str. 60. Ovi podaci su iz neobjavljenog rukopisa generala i ministra Trifunovića koji je radio relaciju Kombinovane divizije u Cerskoj bici. 
Albanije i da Srbija nema razloga za brigu, drugi izveštaji sa terena govorili su da je i sam general Poćorek dolazio u izviđanje na Drinu iako su manevri službeno najavljeni na prostoru između Sarajeva i Mostara. Takođe je javljano da je vojna stoka izdeljena na čuvanje u pograničnim selima i da je vojne inspekcije obilaze. Bilo je i drugih dojava sličnog sadržaja. ${ }^{23}$ Sve je to delovalo krajnje zabrinjavajuće, kao i odbijanje austrougarske vlade da se postigne trajniji sporazum sa Srbijom.

Načelnik Obaveštajnog odeljenja po prirodi svog posla bio je zadužen da razvija zagraničnu obaveštajnu mrežu kakvu su razvijale sve zemlje onog vremena. Kada se vlada u jednom trenutku uplašila da bi pojedine aktivnosti nad kojima ona nema kontrolu mogle izazvati Austro-Ugarsku, tražila je preko ministra vojnog izjašnjenje potpukovnika Dimitrijevića o celoj akciji. U raportu, koji je je jedan od retkih sačuvanih predratnih svedočenja o kasnije spornoj istoriji, Apis je objasnio aktivnosti Radeta Malobabića na razvoju obaveštajne mreže i potrebu da se kuriri snadbeju oružjem za ličnu zaštitu jer bi u slučaju pogoršanja situacije njihov prelaz granice i prenošenje izveštaja bili izuzetno opasni. Potpuno je stao iza pouzdanosti Malobabića, koga su preporučili majori Milan Vasić i Dimitrije Pavlović, koji su sa njim sarađivali u godinama pred balkanske ratove. Apis navodi da je ideja za prenos oružja bila Malobabićeva: "Tom mi je prilikom Malobabić izneo potrebu da bi nosioci izveštaja (kuriri) i odlučniji poverenici trebali, da imaju kakvo oružje za samoodbranu i predložio mi da bi te ljude trebalo naoružati revolverima. Ja sam se saglasio sa tim njegovim predlogom, i odobrio sam mu nameru, da sa sobom ponese četiri revolvera sa potrebnim brojem metaka." Apis je dalje razlagao da je smatrao da za ovaj rad treba zbog tajnosti da zna malo lica, pa i onih službenih. Malobabić je skrenuo pažnju da iz Narodne odbrane pokazuju veliku radoznalost za njegov rad za Generalštab (Apisa - M. B.). Apis kaže da time nije vršio "naoružavanje našeg stanovništva u Bosni". ${ }^{24} \mathrm{O}$ prenosu bombi pukovnik je tvrdio u izjašnjenju da mu nije ništa poznato. Na kraju raporta i u vezi sa policijskim prijavama, Apis traži od nadležnih vojnih organa "da učine potreban korak i da se Narodnoj odbrani, u koliko je ona ovlašćena za rad van granica, dostavi, da njen rad treba da je na usluzi a ne na smetnji radu Gl. Đeneralštaba i da radoznalost njenih članova za zagranični rad vojnih vlasti nije na svom mestu i

23 Документи о спољној политици Краљевине Србије, (даље: ДСп), књига VII, свеска 2, 1/14 мај - 22 јули/4 август 1914, приредили В. Дедијер, Ж. Анић, Београд, 1980, док. 26, 104, 166, 175, 176, 280.

24 Bombe niko nije video, samo su policijski organi imali dostave na osnovu pretpostavke o težini (!) kofera koji je jedan podnarednik prenosio. 
izlazi van granica njenih zadataka. Za policijske vlasti molim, da se izdadu potrebna uputstva, kako bi se izbegle štetne posledice za rad Gl. Đeneralštaba i izbegla nepotrebna trenja i sukobi pri ovome radu."25

Ako su verodostojne beleške Popovića o njegovom susretu sa Apisom u ratu 1915, prvom posle Sarajevskog atenta, pukovnik Dimitrijević je saopštio tada sledeće:

„Bio sam ubeđen da je projektovani manevar u Bosni pretekst za upad Austrije u Srbiju, na čelu sa glavnokomandujućim Austrijske vojske, prestolonaslednikom Francom Ferdinandom. I ja sam u duši strahovito strahovao od tog ... Kakva je bila naša vojnička situacija, to ti je bilo poznato: mogli su pustiti samo jednu-dve konjičke divizije u Srbiju pa ne bi imao ko da ih zaustavi. Dok bi naše trupe pristigle iz južnih krajeva, Srbija bi bila pregažena. Ceo svet, pa i sami mi našli bi se pred svršenim činom. I zato kada je kod mene došao jednog dana u kancelariju Tankosić, i rekao: 'Ima nekih mladića Bosanaca, dosadiše mi moleći da im dopustim da odu u Bosnu - hoću li da ih pustim?' - ja sam, doista, toga trenutka, nerazmišljajući dalje, kazao: 'Pa, pusti ih!' Tankosić mi je tada rekao, da ti mladići, po dogovoru sa drugovima iz Bosne, hoće da pokušaju nešto protiv Ferdinanda. Pravo da ti kažem, toga sam trenutka pomislio, da je nemoguće da takav atentat uspe, i da možda neće doći do njega. Pretpostavljao sam da će Austrijski Prestolonaslednik biti tako čuvan i osiguran da mu se ne može ništa dogoditi; u najboljem slučaju, da može doći do kakva incidenta da uvide da je opasno napadati na Srbiju. U svakom slučaju, nisam mogao pretpostaviti ni u snu da takav atentat može biti povodom za rat protivu Srbije ... Ipak, kada sam posle nekog vremena, razmislio malo više o toj stvari, rešio sam da pokušam da se prebačeni mladići vrate, i da se na svaki način spreči atentat. Taj pokušaj učinjen je preko četnika Đure Šarca. Bilo je dockan. Atentatori, kako ova dvojica što su otišli iz Srbije, tako i oni koji su se zatekli u Sarajevu, nisu hteli da čuju za to." 26

Sledeće, posebno motivisano svedočenje koje je Apis ostavio u pismenoj formi bilo je dato Vojnom sudu za oficire u Solunu. U njemu Apis svu odgovornost preuzima na sebe $u$ želji da spreči osudu Radeta

25 ДСП, књ. VII, Св. 2, док. 230, стр. 363-366. Apis je napisao izjašnjenje 8/21. juna a načelniku je prosleđeno preko pukovnika Milivoja Zečevića sledeći dan.

26 Ч. Поповић, "Сарајвски атентат и организација 'Уједињење или Смрт"”, Nova Evropa, knj. XXV, br. 8, 26. jul 1932, str. 407-408. Ovo bi se poklopilo sa svim svedočenjima, pa i onima u sudskim procesima u Sarajevu i drugde gde su učesnici tvrdili (a kasnije između dva rata i pisali) da su se oni prvo u nameri obratili Ciganoviću, koji in je povezao sa Tankosićem oko nabavke njihovog oružja. 
Malobabića i Muhameda Mehmedbašića, svojih obaveštajca koji su radili na teritoriji Bosne. Za Radeta su srpske vlasti 1914. sumnjale da je austrougarski špijun i uhapsile ga. $U$ tom pisanom svedočenju Apis se dotiče saradnje i sa ruskim vojnim atašeom u Beogradu Artamonovim. U ovom pismu se decidirano kaže da je ova saradnja bila isključivo u funkciji obaveštajnog rada i međusobne pomoći, a ne po pitanju organizovanja atentata. Apis je napisao: „Osećajući da se Austrija sprema za rat sa nama mislio sam, da će nestankom prestolonaslednika austrijskog Ferdinanda vojnička stranka i struja, kojoj je on na čelu bio, izgubiti svoju jačinu i da će na taj način ratna opasnost biti od Srbije otklonjena ili će bar za nešto biti odložena, te sam zbog toga angažovao Malobabića da prilikom zakazanog dolaska Ferdinandovog u Sarajevo da organizjuje atentat na njega."27

Uz podsećanje na strahove srpskih aktera, ovo je svakako prilika da ponovo skrenemo pažnju na jedan poodavno objavljeni dokument iz francuskog diplomatskog arhiva o postojanju istih ideja u javnosti onog doba početkom 1913. godine. Pariski list Paris-Midi je 1. i 2. januara 1913. objavio članke Morisa de Valeta (Maurice de Walette), koji je, praveći aluziju na opasnost koja evropskom miru preti od izvesnih sila, bez ustezanja prozvao upravo po svom mišljenju najistaknutiju silu rečima: "da li anarhista koji bi ubio austrijskog nadvojvodu-naslednika ne bi svet poštedeo reka krvi i suza". Ovo nedvosmisleno mišljenje i možda nameran podstrek izazvao je uzbuđenje u austrougarskoj ambasadi i bio ocenjen u Beču kao podsticaj na ubistvo. U Ke d'Orseju je ovo bilo odmah primećeno pa je usledila poluzvanična intervencija kod Valeta i on je 3. januara objavio jedan umirujući tekst. Međutim, ta izjava nije se učinila dovoljnom austrougarskoj vladi, koja je svome ambasadoru u Parizu naložila da zatraži sudsko gonjenje lista Pari-Midi. U cilju smirenja međunarodnog incidenta Poenkare, tadašnji premijer i ministar inostranih poslova, obratio se ministru pravde s molbom da naredi da se povede sudska istraga protiv lista. ${ }^{28}$

Prema memoarima grofa Černina, poslednjeg austrougarskog ministra inostranih poslova i savetnika nadvojvode Franca Ferdinanda, prestolonaslednik mu se žalio još leta 1913. kako mu masoni rade o

27 Милан Ж. Живановић, Пуковник Апис, Солунски процес хиљаду девесто седамнаесте, Београд, 1955, стр. 556, 557, 559 (факсимил писма).

28 Temoignages français sur les Serbes et la Serbie / Francuzi o Srbima i Srbiji 19121918, (uredio Mihailo Pavlović), Narodna knjiga, Beograd, 1988, str. 99-100 (dok. na francuskom), str. 264-265 (dok. u prevodu). Dokument na memorandumu ministarstva spoljnih poslova, ADMAE, Politique étrangère. Turquie. Guerres balkaniques, XXVI, 16-25 janvier 1913, list 71 (recto et verso). 
glavi i „pomenuo imena nekolicine austrijskih i mađarskih političara koji svakako učestvuju u zaveri". ${ }^{29}$

Istražni sudija u Sarajevu Pfefer je u svojim intervjuima govorio o nedozvoljeno slabim merama obezbeđenja nadvojvode i nedvosmisleno je insinuirao da je "Sarajevski atentat išao na ruku izvjesnim austrougarskim krugovima". To je ponovio i u svojoj knjizi. ${ }^{30}$

$\mathrm{Na}$ drugoj strani, austrijska revizionistička škola se uprla da dokaže da je Ferdinand bio čovek mira, te da u Konopištu na sastanku sa nemačkim carem nije bilo reči o ratu. ${ }^{31}$

U srpskoj istrazi o boravku Principa i Čabrinovića u Beogradu pre atentata utvrđeno je da je Princip, veoma siromašan, založio kaput da bi otputovao, o čemu je ostala priznanica, a da je Čabrinović radio u Državnoj štampariji. "Privukao je na sebe pažnju vlasti koje su se odlučile da ga zbog političke nepouzdanosti proteraju. Međutim, austrougarski konzul se, na Čabrinovićevu molbu, pismeno obratio policiji sa izjavom da je navedeno lice austrougarski državljanin, da ne izaziva sumnje i usled toga je insistirao da mu se produži pravo daljeg boravka u Beogradu. Kao što se vidi, ono što je grof Ponkrac kazao Hartvigu u potpunosti se potvrdilo." 32

Ako je još uvek malo izvornih dokumenata koji bi sa sigurnošću potvrdili stvarnu meru upletenosti pukovnika Dimitrijevića, organizacije "Ujedinjenje ili smrt" u ohrabrivanju pripadnika Mlade Bosne ili samostalnom organizovanju sarajevskog atentata, na svoju ruku, istoričari ne oskudevaju u teorijama, tvrdnjama "iz druge ruke". U tome su imale ulogu ne samo propagandne potrebe onog vremena

${ }^{29}$ Count Ottokar Czernin, In the World of War, London, 1919, str. 46. (navedeno prema: V. Dedijer, Sarajevo, str. 773, nap. 16).

30 Leo G. Pfefer, Istraga u Sarajevskom atentatu, Zagreb, 1938. U Nemačkoj su ga napali da knjiga koristi "poznatoj tezi o neodgovornosti srpske vlade za izvršenje atentata". Berliner Monatshefte, 7-8, 1938 (navedeno kod: V. Buha, n. d., str. 102, nap. 277). Pored intervjua u zagrebačkom Obzoru, Pfefer je u kraćem članku za Novu Evropu (1937) objasnio razloge pisanja.

31 Upravo suprotno beleži Štrandman iz vremena svog odmora u Veneciji juna 1914. Nije imao pune informacije o sastanku Viljema i Ferdinanda u dvorcu Miramar na Jadranu i 12. juna u Konopištu, za koje su mu javljali iz Beograda, pa je on iskoristio priliku u razgovoru sa baronicom Ambrozi, suprugom savetnika austrougarskog poslanstva u Rimu. "Ona mi je, uz osmeh, kazala da se tu radi o tajanstvenoj 'zaveri' protiv Srbije. Na moj izveštačen prigovor da je takva kombinacija neverovatna, ona je dodala da se ne radi samo o Srbiji nego i o stvaranju nezavisne Poljske, kao i o širim planovima preuređenja Evrope, u kojima će biti mesta za sinove nadvojvode Franca Ferdinanda - Maksimilijana i Ernesta" (Štrandman, n. d., str. 258).

32 Štrandman, n. d., str. 266. 
(Nemačka, Austro-Ugarska) nego i lični odnosi pa i međusobne omraze, posebno kada je srpska strana u pitanju.

Navedimo da je jedna levičarski orijentisana grupa jugoslovenskih emigranata u Beču okupljena oko La Fédération Balkanique 1924. i 1925. optužila nekadašnjeg prestolonaslednika Aleksandra da je on odgovoran za ubistvo Franca Ferdinanda. Tu optužbu je ponovio Alfred fon Vegerer (von Wegerer) u članku "König Alexander und die Attentäter von Sarajevo". ${ }^{33} \mathrm{U}$ spisima procesa u Sarajevu našle su mesto glasine koje je proturala austrougarska policija da su za atentat odgovorni Miroslav Spalajković i princ Đorđe Karađorđević. Časopis Balkanska federacija je dalje razvijao teze austrijskih profesora Jozefa Kolera i jezuite Antona Puntigama iz 1918. da je za sve kriva Rusija. Posebno se istakao svojim tekstovima Nikola Nenadović. Njihove teze je prihvatao novinar Lepold Mandel u bečkoj štampi i Francuz Viktor Serž u časopisu Klarte (Clarté, 1925). Poslednji se pozivao na pukovnika emigranta Božina Simića koji je posle Beča došao u Pariz. Simić mu je navodno govorio o vezama Dimitrijevića i Rusa. Nemački časopis Kriegsschuldfrage je ovo prihvatio kako iz pera nemačkih autora Luca i Vegerera ${ }^{34}$ tako i srpskog disidenta Miloša Bogićevića (1925). Odatle će američki istoričar Barns (Barnes) ${ }^{35}$ prihvatiti tezu Luca da je Sazonov bio umešan u atentat (navodna izjava "evropski mir ne bi bio ugrožen ako bi Franc Ferdinand bio sklonjen sa puta"). O Rusima kao vinovnicima atentata pisao je Miloš Bogićević u knjizi Proces (Le Procès de Salonique, Paris, 1927, str. 144). U istom duhu pisali su sovjetski istoričari Pokrovski i Poletika u časopisima Proleterska revolucija i Istorik-marksist (1929). Oni su pisali "da postoje jaki razlozi za sumnju da je nekoliko predstavnika ruske vlade, Hartvig i Artamonov pouzdano, a Sazonov i Generalštab verovatno", znalo za pripremu atentata. Poletika je o tome u sličnom tonu pisao i u svojoj knjizi Sarajevsko ubistvo (1930, str. IX), navodeći da je atentat bio "organizovan pod pokroviteljstvom srpske obaveštajne službe, a po nalogu Rusije". Slično je pisao Buharin u listu Izvestija (28. jun 1934). Posle Drugog svetskog rata Poletika se odrekao svojih ranijih stavova i u svojoj novoj knjizi naveo da su mu raniji izvori bili članci Viktora Serža

33 A. W. u: Kriegsschuldfrage, Berlin, jul 1926, str. 485-489 (navedeno prema: V. Dedijer, Sarajevo, str. 772, nap. 6).

34 Dr Alfred Wegerer, Der Ausbruchdes Weltkrieges, Hamburg, 1939. Vegerer je bio stalni urednik i saradnik Kriegsschuldfrage i Berliner Monatshefte. Od 1923. do kraja (1937) bio je na čelu Centralne službe za istraživanje uzroka rata (Zentralstelle für Erforschung der Kriegsursachen).

35 Harry Elmer Barnes, The Genesis of the World War, New York, 1926. 
u listu Klarte. Zanimljivo je da se na ceo slučaj osvrnuo i Viktor Serž u svojim memoarima 1951. On je tada izneo da je informacije dobio od pukovnika Božina Simića i Miloša Bogićevića (sic!). ${ }^{36}$ Oko ove epizode treba dodati da je čuveni Albertini u prisustvu Čede Popovića (1937) pokazao članak iz Klartea Božinu Simiću, ovaj je povukao optužbu protiv Hartviga, ali je i dalje tvrdio da su za pripreme znali Artamonov, verovatno ruski generalštab, ministar vojske Suhomlinov ili neki veliki knez (Albertini, II, str. 83). ${ }^{37}$ Sam general Viktor Artamonov je ovo negirao kao izmišljotinu navodeći da je za Rusiju, kao i za Srbiju, to bila nesreća jer nijedna od njih, nakon iskušenja prethodnih godina, nije bila spremna za ratne napore. ${ }^{38}$

Bez obzira na spekulativnu osnovu ovih tvrdnji, Vegerer pre rata, a Hans Ibersberger (Übersberger) pre i posle rata nastavili su da brane ovu hipotezu. ${ }^{39}$

Kada su svetlo dana (2009) konačno ugledali memoari Vasilija Štrandmana, nekadašnjeg prvog sekretara ruskog poslanstva u Beogradu a potom otpravnika poslova posle smrti Hartviga u julu 1914, mogli smo videti da uprkos izvodima ili celim dokumentima koje je sačuvao iz tog vremena nema insinuacija ni informacija o udelu pukovnika Artamonova. Njih dvojica su bili i u međuratnom periodu kolege u Beogradu, sve do okupacije. Ipak saznajemo da je pukovnika atentat zatekao na dvomesečnom odmoru u Švajcarskoj i na Jadranu. Poslanik Hartvig ga nije požurivao da se vrati na dužnost posle atentata, a sam se spremao na lečenje i odmor u Italiji. U Italiji se na šestonedeljnom lečenju i odmoru nalazio i Štrandman, koji se samoinicijativno vratio sluteći komplikacije. Službena Rusija je još od februara 1914. odbijala da isporuči Srbiji 100.000 pušaka, traženu artiljeriju i opremu. ${ }^{40}$ To nije učinila ni na urgencije u junu i julu, kako se to ne bi tumačilo kao ugrožavanje mira. „Bilo mi je saopšteno da je, uzimajući u obzir želju Rusije da se do rešenja austro-srpskog konflikta dođe na miran način, trebalo izbegavati sve što bi protivničkoj strani moglo dati povoda za optuživanje Rusije za neiskrenost i podstrekavanje Srbije da se

36 V. Serge, Mémoires d'un révolutionnaire de 1901 à 1941, Paris, 1951, str. 198-199, (navedeno kod: V. Dedijer, Sarajevo, str. 772, nap. 9).

37 Isto; Luigi Albertini, Le Origine della Guerra del 1914, I-III, Bocca, Milano 1942-43 (eng. prevod: The Origins of the War of 1914, I-III, London, 1952-1957 (1965).

38 V. Artamonov, "Erinnerungen an meine Militärattachezeit in Belgrad", Berliner Monatshefte, 7-8, 1938 (navedeno kod: В. Буха, Н. Д., 87, нап. 231).

39 H. Übersberger, Östereich zwischen Russland und Serbien, Köln - Gratz, 1958, II, str. 239-305 (navedeno kod: V. Dedijer, Sarajevo, str. 773, nap. 9).

40 Никола Б. Поповић, Србија и Царска Русија, Службени гласник, Београд, Друго издање, 2007, стр. 68-70, 135-143. 
suprotstavi. Eto, zbog čega je”, piše Štrandman, "slanje naoružanja u tom trenutku bilo smatrano potpuno neprihvatljivim pa je izdata naredba da se pričeka dok se politička situacija ne razjasni."41 Oružje je krenulo za Srbiju tek u avgustu 1914. posle ulaska svih sila u rat.

Tragove nekadašnje propagande i kontroverzi među savremenicima pratimo u kritičkim opaskama Dragiše Stojadinovića iz 1963. povodom pisanja Miroslava Krleže na stranicama beogradske štampe. Raspravljajući u "Srpskim temama” o Solunskom procesu pisac „Miroslav Krleža zavijeno nam tvrdi: Da je ruski vojni ataše u to vreme, đeneral Artamonov bio inicijator i saradnik pukovniku Dragutinu Dimitrijeviću Apisu u spremanju zavere i izvođenju ubistva austrijskog prestolonaslednika Franca Ferdinanda na Vidovdan 1914. g. u Sarajevu. Čak šta više on taj atentat, koji on naziva 'Djelo', pripisuje u celosti ruskom generalu Artamonovu, a da je o tome mogao znati i Pašić. To što nam iznosi akademičar Krleža, sada 1963. godine ceo svet zna $\mathrm{i}$ istorijski je utvrđeno da je to u ono vreme bila stara austrijska i nemačka teza i da ona ne odgovara istini, te je kao takva odbačena i od austrijske i nemačke vlade (...) Sva akta po predmetu suđenja oficirima u Solunu Nemci su, za vreme okupacije, iskopali u Srbiji i odneli. Jedan deo je stavljen na raspoloženje bečkom profesoru Hansu Ibersbergeru i on je za vreme Drugog svetskog rata pisao o toj temi (a pisao je i pre rata falsifikujući izvesna dokumenta)." ${ }^{\prime 2}$

O tome je $\mathrm{u}$ istom duhu opširno pisala hrvatska štampa za vreme Drugog svetskog rata. Dragiša Stojadinović je pratio tokom rata to pisanje i odmah po njegovom završetku skrenuo pažnju Veljku Mićunoviću, kome je predao jedan broj isečaka. Stojadinović nije siguran da li je ova akcija doprinela da se u Austriji traži pokradena građa Solunskog procesa, ali se ona uskoro ponovo našla u posedu jugoslovenske države. $U$ tom korpusu se nalazio akt koji je Apis povodom atentata uputio sudu. Apis je tvrdio: "G. Artamonovu ovom prilikom nisam saopštio ništa od mojih namera za atentat, a povod za traženje njegovog mišljenja o držanju Rusije našao sam u tome što se naš rad na izveštajnoj službi mogao osetiti pa bi mogao biti pretekst Austrije da nas napadne". "Kao što se vidi", pisao je Stojadinović, "ne može biti ni reči o kakvoj zajedničkoj inicijativi i saradnji između

41 Василиј Штрандман, Балканске успомене, књига I, део 1-2 (превео са руског Јован Качачки), Жагор, Београд, 2009, стр. 244, 250-251, 334.

42 NBS, P 736/III/69. Dragiša Stojadinović, Otvoreno pismo Jugoslovenskoj akademiji nauka, Zagreb, Srpskoj akademiji nauka, Beograd i Srpskoj matici u Novom Sadu, povodom tekstova M. Krleže "Srpske teme" u beogradskom listu Politika, posebno nastavka pod naslovom „Пашић и Солунски процес", Политика, 9. јуна 1963. 
đenerala Artamonova i Apisa na ubistvu austrijskog prestolonaslednika u Sarajevu. U izvršenom falskifikatu od strane austrijskog profesora univerziteta Hansa Ibersbergera, čitao sam istu tvrdnju koju nam sada iznosi u 'Srpskim temama' pisac Miroslav Krleža, a naime da su Apis i Artamonov zajednički planirali i sarađivali na ubistvu Ferdinandovom." Stojadinović podseća da je falsifikat austrijskog profesora objavljen u časopisu Spoljna politika (Auswertige Politik, Hamburg, sveska br. 7, jul 1943) i zaključuje svoje obraćanje konstatacijom da "za ovakav svoj postupak pisac Miroslav Krleža duguje, i našoj i svetskoj javnosti, objašnjenje na osnovu kakvih je drugih svojih podataka sem ove Gebelsove propagande, zasnivao svoje tvrđenje, koje čitamo u 'Srpskim temama'".43

\section{Usporen rad na pripremi srpske građe i tretiranje pitanja u javnosti}

Srpska vlada je, slično drugim vladama, odmah po otpočinjanju rata izašla sa jednom zbirkom diplomatske građe, a potom sa još jednom 1915. godine. ${ }^{44}$ Inicijativom Vojislava Jovanovića Maramboa, načelnika arhiva MIP-a, pokrenuta je akcija objavljivanja građe i pisanja knjige o odgovornosti za Prvi svetski rat i srpsko-austrijskim odnosima. Jovanović se obratio ministru spoljnih poslova Marinkoviću 30. maja 1927. sa predlogom da Ministarstvo izda tu zbirku. "Kraljevina je dužna da to učini i zato što su prethodne zbirke nepotpune, što su odštampane sa puno grešaka i što je još 1924. godine objavljena vest da se na ovom poslu radi (...) Ovakvom zbirkom bi se, na najcelishodniji način suzbila propagandna akcija bivših neprijateljskih država o ratnoj odgovornosti Srbije. Arhivska građa po ovom pitanju već je sređena, obaveštavao je Marambo ministra Marinkovića." ${ }^{45} \mathrm{U}$ junu iste godine, na poziv ministra, posla su se prihvatili Slobodan Jovanović i Jovan Jovanović Pižon, uz punu pomoć Maramboa. U januaru 1928. radna grupa Ministarstva opredelila se za naslov Plava knjiga o ratnoj odgovornosti. Na predlog Slobodana Jovanovića trebalo je započeti sa

43 Isto.

44 Дипломатска преписка о српско-аустроугарском сукобу, Ниш, 1914; Српско-аустријски и европски рат: Дипломатски и други документи, I, Ниш 1915.

45 Радош Љушић, „О судбини Ћоровићеве књиге 'Односи између Србије и АустроУгарске у XX веку'", (поговор књизи, Владимир Ћоровић, Односи између Србије и Аустро-Угарске у XX векУ, Библиотека града Београда, 1992, стр. 824). 
1903. godinom. Slobodan Jovanović je potcrtavao važnost posla jer se pored neprijateljskih država počeo javljati i jedan broj istoričara koji su sve više bacali odgovornost na Srbiju i Rusiju. Kako su zbog ratnog uništavanja postojale praznine u građi, poslat je cirkular poslanstvima u Beču, Berlinu, Parizu, Londonu, Bukureštu, Atini, Sofiji i konzulatu u Budimpešti da se sačine prepisi dokumenata iz njihovih arhiva od 1903. do 1914. a koji se tiču srpsko-austrougarskih odnosa.

Deo građe su bili zaplenili Austrijanci u manastiru Ljubostinja, gde je u povlačenju arhiva bila zakopana, a deo Bugari. U Beogradu su zaplenjene arhive Nikole Pašića, Momčila Ninčića, Božidara Jankovića, Jovana Skerlića, Milorada Pavlovića i drugih. Selekcionirani dokumenti već su korišćeni, najčešće van konteksta, za nemačku Belu knjigu (1919), sudske procese u Sarajevu i Banjaluci i prve radove Miloša Bogićevića. ${ }^{46}$ Poslanik u Beču Cincar Marković je 30. januara 1929. skrenuo pažnju austrijskom ministru na činjenice otuđivanja građe iz Srbije, arhiva Bosne i Hercegovine, kao i crnogorskih arhiva i urgirao da se ona vrati. Usput im je preneo da ima dokaze o falsifikovanju dokumenata u Beloj knjizi.

Radna grupa MIP-a je stala na stanovište da bi konačnu redakciju građe i pisanje knjige o srpsko-austrougarskim odnosima trebalo poveriti istoričaru. Taj zahtev je postavljen jula 1930. a Ministarstvo je odabralo Vladimira Ćorovića. Prvobitna želja je bila da se knjiga i dva toma građe pojave do 1932. godine. Uspelo se da do 1933. bude objavljen prvi tom građe. Stojan Gavrilović je izašao odmah sa idejom da se knjiga istovremeno pojavi i na srpskom i na engleskom jeziku. Sedmog jula 1932. je potpisan ugovor sa Stanford univerzitetom. Američki profesor Ralf Luc (Ralph Lutz) je bio angažovan da napiše predgovor. Gavrilović i Luc su se sastali u Berlinu, gde je profesor informisan o sadržaju knjige. U predgovoru bi Luc objasnio zašto se ovo delo o ratnoj odgovornosti štampa u ediciji Stanforda. To je bilo neophodno kako bi se istakao naučni značaj a ne propagandni karakter publikacije. Na kraju, Luc bi prikazao sve dotadašnje edicije koje donose građu o ratnoj odgovornosti, među njima i prvu knjigu Diplomatske

46 Isto, str. 826, 827. Iako je Bogićević u predgovoru pisao da poseduje originalna dokumenta, kao i veliki broj kopija, nije Marambou i drugima bilo teško da utvrde da je to otkopana građa iz Ljubostinje. Radi se o knjizi Kriegsursachen, Beiträge zur Erfoschung der Ursachen des Europäischen Krieges mit spezieller Berücksichtingung Russlands und Serbiens, Zürich, 1919. Zapravo Miloš Bogićević je samo potpisao ovu knjigu a nju su priredili Hans Šiler i Hans Fernele. Na osnovu jednog dokumenta MIP je utvrdio da Bogićević nije imao vlastite prepise. 
prepiske Kraljevine Srbije. ${ }^{47}$ Knjiga je konačno bila u srpskom izdanju odštampana 1936, ali je svega nekoliko primeraka došlo do javnosti. Predsednik vlade Milan Stojadinović je smatrao da je ne treba rasturati, najverovatnije u interesu poboljšanja jugoslovensko-nemačkih odnosa. Englesko izdanje nije izašlo i ne zna se gde je rukopis prevoda.

Kraljevska vlada je povodom pisanja Vegerera i Viznera o umešanosti regenta Aleksandra u Sarajevski atentat uputila preko poslanika Josipa Smodlake demarš, ali je dobila prilično ciničan odgovor. Samo pitanje krivice za rat pokrenuo je kralj Aleskandar 1926. u razgovoru sa nemačkim poslanikom Olshauzenom. „Aleksandar je izrazio nezadovoljstvo stalnim nemačkim spočitavanjem ratne krivice Srbiji i istakao da u njoj 1914 godine niko nije pomišljao na rat, ako ni zbog čega drugog onda zbog vojne nemoći u odnosu na velike sile." Olshauzen je objašnjavao da Nemačka „istorijskim istraživanjima" mora da ospori član 231 Versajskog ugovora. ${ }^{48}$

Mnogi savremenici nisu znali za ove ponešto okasnele poteze Ministarstva inostranih poslova i pojedinih profesora, a izgleda ni pojedine diplomate i predstavnici na strani.

Urednik Nove Evrope Milan Ćurčin se u aprilu 1929. godine obratio javnosti, pre svega upućenim savremenicima, da se ozbiljno prihvate svedočenja i iznošenja dokumenata o pitanju koje se već čitavu deceniju pretresalo u svetu - odgovornosti za rat. Ćurčin nije mogao shvatiti da se ćuti i time daje za pravo nemačkim i austrijskim nastojanjima, kao i revizionistima na svim stranama koji su tvrdili da postoji odgovornost službene Srbije za sarajevski atentat, drugim rečima za izbijanje rata: „Neki naši 'leni rodoljubi' i novinari optimiste još uvek veruju, ili bar tako tvrde, da nikoga više ne interesuju razna 'pisanija' o uzrocima Svetskog rata, za koje bi Nemci da prebace krivicu na Srbiju i na Rusiju, i na Francusku i Veliku Britaniju, ili bar da je podele sa svima njima; i kažu da je ovo pitanje jednom za svagda rešeno u Versaju, ugovorima o Miru. Međutim, vidimo da svetska javnost ne prestaje raspravljati o ovom pitanju, i pretresati ga sa svih strana, do u najmanje pojedinosti, tako da literatura o odgovornosti za Svetski rat, ili o uzrocima Rata i što je s tim u vezi postaje nepregledna, pa ne samo da ima časopisa posvećenih samo tome predmetu nego ima i publicista i naučnika 'stručnjaka' koji o niočem drugom ne pišu nego

47 Isto, str. 830, 832.

48 В. Буха, н. Д., стр. 98, (prema: Nedatirana beleška Olshauzena, ADAP, Serie B, Band III, 362) 
o njemu." 49 Upozorivši na sve što preduzima Nemačka, o čemu se piše kod saveznika, posebno je ukazao na kretanja i stavove istoričara u Sjedinjenim Državama. Molbe Sitona Votsona srpskim političarima da progovore i prilože dokumenta ostajale su neuslišene. ${ }^{50}$ Tek kada su se zavadili Nikola Pašić i Ljuba Jovanović, Pašić je 1926. ustvrdio da je Jovanović slagao navodeći da je vlada znala za atentat, ili bar nekoliko njenih ministara. ${ }^{51}$ Pašićevu izjavu, mada datu sa zakašnjenjem, Ćurčin je pozdravio, a posebno englesko i srpsko izdanje Votsonove knjige Sarajevo (1926), koja je po njemu bila sjajna.

Međutim, te 1929. Ćurčin je upozorio na nove momente, na štetan rad dr Bogićevića, dr Milana Šuflaja, naših branilaca nemačke teze i na Vegererove zlurade prozivke srpske vlade za neobjavljivanje Plave knjige. ${ }^{52}$ Dr Šuflaj je nastojao da omalovaži vrednost Votsonove knjige, dok je dr Bogićević objavljivao knjigu za knjigom. ${ }^{53}$ Njegov najjači argument je bilo samohvaljenje da je on vredno skupljao građu srpske vlade i poneo je sa sobom kada je 1915. konačno dezertirao iz srpske diplomatske službe, odlazeći najpre za Švajcarsku, a potom za Nemačku, gde je bio otpravnik poslova od 1907. do 1914. Protivnik Pašića iz krajnje ličnih razloga, a potičući iz ugledne porodice, pristalica Obrenovića, izdao je svoju zemlju i stavio se u službu Nemačke. Taj rad je nastavio do smrti 1938. (u Beču).

Srpska štampa je, istina, određenim povodima reagovala. Tako je govor predsednika Nemačke (Fon Hindenburga), prilikom otkrivanja spomenika na Tanenbergu 18. septembra 1927. i oštrih odgovora koji su sledeli u Francuskoj, beogradska štampa osudila kao revizionizam, ceneći da govor predstavlja „opasnu obmanu koja u narodu mora prirodno podhraniti ideju revanša" i da bi "novo odmotavanje jednom

49 "Odgovornost za rat", Nova Evropa, knj. XIX, br. 8, 26. april 1929, str. 209-211.

50 Votson je upozoravao da je "Sarajevski atentat ponovo pred svetskom javnošću” i "krajnje je vreme da Beograd jednom uvidi, da će se dalje ćutanje po ovom pitanju shvatiti kao priznanje krivice" (isto, str. 210).

51 Radi se o beleškama i izjavi ministra Jovanovića objavljenoj u zborniku $К p B$ Словенства (1925) koji je pripremio ruski emigrant Aleksej Ksjunjin.

52 Alfred von Wegerer, "Wo bleibt das serbische Blaubüch?", Kriegsschuldfrage, April 1929. Ministarstvo inostranih dela SHS obećalo je bilo 1924. jednu takvu knjigu ("Odgovornost za rat", Nova Evropa, knj. XIX, br. 8, 26. april 1929, str. 211).

53 Uvodnik (Milan Ćurčin), "Odgovornost za rat", Nova Evropa, knj. XIX, br. 8, 26. april 1929, str. 211. Radi se o knjigama: Miloš Bogićević: Causes of the War, Amsterdam - Roterdam, 1919 (London, 1920); Les Procès de Salonique, Paris, 1927; Le Colonel Dragoutine Dimitriévitch-Apis, Paris, 1928; Die Auswartige Politik Serbiens, I, II, III, Berlin, 1928-1931. Bogićević je bio redovni saradnik Kriegsschuldfrage i drugih publikacija koje su tretirale pitanje odgovornosti za rat. 
za svagda rešenog pitanja ratne odgovornosti značilo buđenje duha starog neprijateljstva i jedan korak unazad". ${ }^{54}$

Pored važnih članaka na stranicama Nove Evrope, ${ }^{55}$ radova savremenika o Mladoj Bosni, treba pomenuti knjigu Stanoja Stanojevića Ubistvo najvovode Ferdinanda (Beograd, 1923). Stanojeviću su savremenici s pravom zamerali da je bio na pozicijima organizatora Solunskog procesa i da nije doprineo pravom rasvetljavanju ovog osetljivog pitanja. U krugu revizionista taj rad je smatran stavom vlade. ${ }^{56}$

Zapažanja i zaprepašćenost indolencijom državnih organa po ovom pitanju izneo je još jedan prečanin - Miloš Crnjanski. Kao ataše za štampu u poslanstvu Kraljevine u Berlinu susreo se sa delovanjem dr Miloša Bogićevića. Za Crnjanskog taj čovek je bio "agent Nemaca". On je cenio "da je nemačka diplomatija, i štampa, činila sve što je mogla da odgovornost za rat, zbaci sa svojih pleća i krivicu prebaci, za rat na Srbiju. To jest ceo srpski narod". Ona je u tome pored hrvatske emigracije imala pomoć i od Bogićevića. Svestan šta je Srbija propatila i dala za pobedu i oslobođenje, nije mogao da shvati indolentan odnos Kraljevine, a posebno poslanika Živojina Balugdžića. Crnjanski se susreo po prvi put sa pogledima koji su pre vodili računa o unutrašnjopolitičkim razmiricama (sujetama, mržnjama) nego o državnom interesu. "Ono što me zaprepastilo", piše Crnjanski, "bile su Bogićevićeve knjige o odgovornosti za rat, za koji je krivio Srbiju (...) To je bilo najgore što je o krivici za rat rečeno. Balugdžić se mom zaprepaštenju smejao. Veli, sve bi bilo Bogićeviću oprošteno, mogao bi i da se vrati u Srbiju, samo da TO nije štampao. Za ono ranije, smatralo bi se, kaže, da je

54 В. Буха, н. Д., стр. 32 (prema: Време, 2. октобар 1927).

55 Uvodnik (M. Ćurčin), "Današnja Jugoslavija”, NE, 21. mart 1924; M. Ćurčin, "Krivica za rat", NE, 1. april 1924; Seton-Vatson R. W., "Ko je odgovoran za ubojstvo Franje Ferdinanda?", NE, 11. maj 1925; M. Ćurčin "Radikali i Sarajevski Atentat”, NE, 11.maj 1925; Isti, "Pitanje odgovornosti za Rat", NE, 1. jun 1925; Isti, "G. Pašić i Sarajevski Atentat", NE, 11. maj 1926; Isti, "Vatsonovo 'Sarajevo'", NE, 11. avgust 1926; Isti, "'Solunski Proces' M. Bogićevića”, NE, 26. jul 1927; Чеда Поповић, „Рад организације 'Уједињење или Смрт' (Гранични официри)”, NE, knj. XVI, 5, 11. septembar 1927; Isti, "Kako je došlo do Rata”, NE, knj. XV, 10, 26. oktobar 1932; Marco (Б. Симић), "Никола Хартвиг (Спољна политика Србије пред Светски рат)”, NE knj. VII, 8, 26. april 1928; Ч. Поповић, „Сарајевски Атентат и организација 'Уједињење и смрт'", $N E$, knj. XXV, 8, 26. jul 1932; Мarco, "Никола Хартвиг и Србија (Поводом дискусије о Светском рату)", NE, XXVI, 6, 26. jun 1933; Leo Pfeffer, "Zašto sam napisao knjigu o Sarajevskom Atentatu", NE, knj. XXX, 9, 26. septembar 1937; Č. Popović, "Sarajevski Atentat i boljševici", $N E$, knj. XXX, 11, 26. novembar 1937.

56 Taj rad je u osnovnim linijama pratio verzije iz knjige: Tajna prevratna organizacija - Izveštaj sa pretresa na vojnom sudu za oficire u Solunu. Po beleškama vođenim na samom procesu, Solun, 1918. 
čovek otišao, zbog Pašića, u opoziciju, pa je malo prekardašio, ali to, što sada radi u Berlinu, u korist Nemaca, prešlo je meru. Godinama je, kaže sklanjao dokumenta i diplomatsku poštu, pa sad ima adute 'protiv kralja', a to ne valja. Zato su sad u Berlin uputili Blažu Barlovca, rođaka kraljevog, u Reparacionu komisiju. Treba Bogićevića, nekako, da odobrovoljimo. Kad sam to čuo opet sam bio zanemeo."57 Mnogo toga je Crnjanskog dovodilo da zaprepašćenosti. Na primer, Balugdžić se nije uopšte pitao da li su dokumenti falsifikovani ili "doterani". Balugžić je obaveštavao svog atašea da su Bogićeviću dokumenta davali Nemci, a verovatno i austrijsko ministarstvo spoljnih poslova (Balhausplatz). Poslanik je više brinuo kako neke stvari mogu loše da utiču na domaće prilike nego o odjecima sa strane. Smatrao je da "mi imamo" Sitona Votsona za to.

Crnjanski je pisao: „Ja sam tada već smatrao celu tu rabotu Bogićevićevu u Berlinu, kao i te kako opasnu, i predlagao svom ministru da na to odgovorimo. Iako, posle rata, niko ne mari, naročito, da utvrdi, KO je, zaista kriv za rat, - pravi krivac za rat, - ja sam mislio da je za našu novu državu, to, što se protiv nje sprema u Berlinu, i širi po svetu, opasno. Balugdžić mi onda reče da Ministarstvo sprema odgovor, na sve to, i da je izrada tog odgovora poverena profesoru Ćoroviću. Međutim ta knjiga tada nije spremljena, ni ugledala sveta, a ono što je o krivici za rat, izašlo iz pera profesora Stanoja Stanojevića, bolje da nije štampano. Samo u partijskoj politici, odgovornost za rat, odigrala je neku ulogu prilikom pokušaja da Pašićev drug, ministar unutrašnjih poslova u Solunu, Ljuba Jovanović, obori Pašića. Pašić je njega oborio. Jedina knjiga, pamflet, koja je bila objavljena protiv pisanja Bogićevića, bila je iz pera Tartalje (dr Oskar), pod naslovom: Izdajica." ${ }^{58}$

Crnjanski je, možda sa više sluha za metode "srednje Evrope", bolje uočavao od njegovog poslanika te razmeštene nemačke lobiste i promotere. Jednog od takvih je pronašao u redakciji lista Berliner Tageblatt - grofa Mongelasa (Max Montgelas). Ista osoba nastavila je

57 M. Crnjanski, Embahade, I-III, knjiga prva, Nolit, Beograd, 1983, str. 89-90. Istu konstataciju će ponoviti jedan mlađi istoričar: „Politički dirigovano prebacivanje odgovornosti za sukob na Srbiju i ostale zemlje iz protivničkog tabora ... takva shvatanja je u sklopu pokrenutog državnog poduhvata valjalo konkretizovati i preinačiti u činjenično utemeljene i naučno verodostojne optužbe protiv Srbije" (B. Буха, H. Д., стр. 6).

58 Isto, str. 90. Knjiga Владимира Ћоровића Односи између Србије и Аустро-Угарске y XX веку izašla je u Beogradu 1936. Ovo delo, utemeljeno na dokumentima, bilo je uskoro po objavljivanju zabranjeno. Ponovo je objavljeno u Beogradu 1992. godine (Енциклопедија српске историографије, Београд, 1997, стр. 689). 
svoju rabotu protiv Srbije i tokom posleratne emigracije u Irskoj "kao da ništa u međevremenu nije bilo." 59

Kao što ćemo u drugom delu ovog članka videti, ovo zapažanje se poklapa sa zapažanjima srpskih istoričara koju deceniju kasnije. Duh nemačko-austrijskih nastojanja između dva rata je preživeo „kao da se ništa u međuvremenu nije desilo" i kao da taj duh političke revizije nije ponovio nesreću.

Istoričar Dimitrije Đorđević upozorava, posredno, na jedan važan segment o kome se mora voditi računa kada se bavimo time kako srpsku istoriju interpretira anglosaksonski svet, posebno ovu temu o odgovornosti za rat. To je delatnost istoričara sa područja bivše austrougaraske monarhije na katedrama i institutima Britanije i SAD-a. Među delatnicima je bilo i onih koji su na srpsku istoriografiju gledali kao na "velikosrpsku".60

„Prema podacima iz 1964. na univerzitetima u Americi i Kanadi stosedamdeset pet naučnika izlagalo je kurseve iz istorije Austrougarske; odbranjeno je sedamdeset i sedam doktorskih disertacija, a pedeset i pet je bilo u toku izrade. Mnogo pre ostalih naučnih društva koja su se bavila posebnim narodima Evrope, u Americi je osnovan Komitet za razvoj studija Habzburške monarhije. U Njujorku je postojao Austrijski institut koji je finansirala vlada u Beču. Neverovatno je bio privlačan taj spoj prošlosti i sadašnjosti, ideja o stvaranju posebne Srednje Evrope kao protivteže Sovjetima, a bilo je i nostalgije za 'starim, dobrim vremenima' i divljenja za bogato kulturno, umetničko i naučno nasleđe Carstva. Ova okolnost je, verujem, bila i ostala veoma značajna za stereotipno shvatanje zapadne i američke javnosti o Balkanu i Srbiji kao nekakvoj tamnoj mrlji preživelog otomanskog nasleđa. Habzburška i nemačka istoriografija, posebno ona između dva svetska rata, nisu mogle zaboraviti srpsko podrivanje Habzburške mo-

59 Isto, str. 90-91. Grof Maks Mongelas je uz Hansa Delbriha, Alberta Mendelsona Bartoldija i Maksa Vebera bio član tzv. "Četvorne komisije" od "nezavisnih Nemaca” koja je od samog početka imala da odgovori na navode Savezničke komisije za utvrđivanje nemačke krivice (R. Lensinga). $U$ toj komisiji je bio i predstavnik Srbije (В. Буха, н. д., стр. 17).

60 M. Bjelajac, G. Krivokapić Jović, Prilozi iz naučne kritike, Srpska istoriografija i svet, INIS, Beograd, 2011, str. 18-19 (prema: Димитрије Ђорђевић, Ожиљци и опомене, књ. III, Београд, 2000, стр. 118, 120. Na dočeku jugoslovenske delegacije na konferenciji "O nacionalnom problemu u Habzburškoj monarhiji u XIX veku” (University Bloomington, Indiana), professor Ante Kadić sa Blumingtona pozdravio je Đorđevića rečima: „Vi pišete velikosrpsku istoriju kakvu je nekada pisao Vladimir Ćorović. To je opšte mišljenje ovde!" Đorđević piše da je Ante u mladosti školovan kod jezuita i upoređuje ga sa pravovernim Dušanom Perovićem iz Beograda koji je delio iste etikete. 
narhije radi ujedinjenja srpskog i ostalih jugoslovenskih naroda. (...) Kasnije u vreme raspada Jugoslavije devedesetih godina, razmišljajući o uzrocima ove srbofobije u američkim i zapadnim krugovima, nalazio sam njihove korene $u$ istorijskom austro-nemačko-srpskom sukobu koji je prethodio Prvom svetskom ratu. Čak je i američki predsednik Klinton (ili onaj koji mu je pisao govor) javno bubnuo da su dva svetska rata izbila na Balkanu." ${ }^{1}$

\section{Istorija nemačkog zataškavanja, propagande i revizije}

Uoči stogodišnjice izbijanja Prvog svetskog rata svakako valja podsetiti u najkraćem na tok jednog političkog procesa koji je nastao u Nemačkoj 1919. i koji je ostavio traga i na današnje dileme, kontroverze i revizije. Takođe, stručnoj publici treba skrenuti pažnju na istoričare i njihove radove koji su se u najskorije vreme bavili ovim pitanjem.

Nemački predstavnici na Konferenciji mira su 22. juna 1919. u načelu prihvatili ugovor, osim pomenutog člana 231 o krivici za rat i tražili su ponovnu diskusiju. Klemanso je odbio i saveznici su zapretili nastavkom operacija. Pod tim uslovima Nemačka pristaje. To je odmah interpretirano kao "nečuvena nepravda". Od tog trenutka počinje politička borba za reviziju, u koju je iz svesnog razloga bila uključena istorijska nauka i nemački profesori. $U$ javnosti je postojao gotovo potpun konsenzus uprkos svim ostalim razlikama. ${ }^{62}$

Krajem rata, unutar revolucionarne vlade u Nemačkoj je bila otvorena debata i inicirano istraživanje problema krivice za rat. Bilo je odlučeno da se štampaju sva dokumenta jasno vezana za izbijanje rata. Inicijativa je potekla od bavarskog premijera Eisnera, koji je sam već dao minhenskim novinama pisma bavarskog poslanika iz Berlina (jul 1914) iz kojih se videlo kako je mala grupa uz sadejstvo elita orkestrirala izbijanje rata. Vlada je za taj posao, 9. decembra, odredila dr Karla Kauckog. Čim je krenuo sa radom, odmah se susreo sa opstrukcijom odgovornih iz straha da će utisak po Nemačku biti nepovoljan. Kada je Kaucki ipak svoj rad privodio kraju u martu 1919,

61 Д. Ђорђевић, н. Д., стр. 120.

62 M. Dreyer, O. Lembcke, Die deutche Diskussion um die Kriegschuldfrage 1918/19, Berlin, 1993 (navedeno kod: В. Буха, Н. Д., стр. 20, нап. 22); Holger H. Herwig, "Clio Deceived. Patriotic Self-Censorship in Germany After the Great War", Forging Collective Memory. Governments and International Historians through Two World Wars, Keith Wilson (ed.), Berghan, Oxford, 1996, str. 91-93. 
nove strukture mu zabranjaju ulazak u Arhiv i traže da vrati sve strogo poverljive dokumente iz svog poseda. Krenulo je opstruiranje i odlaganje objavljivanja. Stare strukture su se dobro organizovale i preuzele pripremu platforme za Mirovnu konferenciju po pitanju krivice za rat. Tek kasnije, posle Konferencije Kaucki objavljuje svoju zbirku. U objašnjenju je naveo: „Politika Centralnih sila godinama pre rata bila takva, da se svetski mir nije održavao pomoću njih, već samo još uprkos njima." 63

Slično Kauckom prošao je profesor prava Herman Kantrovic kome je Istražni odbor Rajhstaga za utvrđivanje uzroka rata dao u zadatak (1923) da izradi međunarodno pravnu ekspertizu o politici nemačke vlade u leto 1914. Radio je na izvornoj građi modelom sudskog procesa. Posao je završio 1927. i njegov zaključak se sveo na tvrdnju da Austro-Ugarska snosi glavnu odgovornost, Nemačka ima veliku odgovornost, dok je na Rusiji ograničena odgovornost. Njegova ekspertiza je nestala u tajnoj arhivi Ministarstva inostranih poslova. Oni nisu bili zadovoljni njegovim nalazom i politički razlog (revizija) je postao stariji. Kantrovic je potom svuda u Nemačkoj bio opstruiran i njegova akademska karijera uništena. Na kraju je bio prisiljen da emigrira. ${ }^{64}$

U avgustu 1919. u Rajhstagu je formirano jedno telo koje je trebalo da otvori pitanje revizije člana 231 Versajskog ugovora. No, telo nije pokazalo operativnost jer su preovladavale svađe starih i novih političkih snaga oko (ranije) odgovornosti. Tada je još postojala volja da se zaista ispita odgovornost pojedinaca sa nemačke strane, ali je to kasnije, splašnjavanjem revolucionarne situacije nestalo. Inicijativa oko revizije potom prelazi u okvir Ministarstva inostranih poslova, gde je formirano odeljenje Kriegschuldreferat. Na početku vodio ga je Bernhard fon Bilov (Prince Bernhard von Bülow). Iz tog centra se vršila koordinacija brojnih privatnih inicijativa i poduhvata na planu osporavanja člana 231 Versajskog ugovora. Odeljenje je imalo zadatak da "sredi" i "očisti" dokumentaciju Ministarstva u pogledu uzroka rata; da objavi ogromnu građu za period 1871-1914. sa ciljem da pokaže "nemačku miroljubivu politiku"; 65 da podržava profesore, jednako kod kuće i na strani, koji su bili voljni da predaju službenu nemačku liniju

63 В. Буха, н. Д., стр. 23, нап. 27 (prema: M. Dreyer, O. Lembcke, n. d., str. 200-207; K. Kautsky, Wie der Weltkrieg enstand, Berlin, 1919, str. 31).

64 A. Mitrović, n. d., str. 28-29.

65 Die Grosse Politik der Europaischen Kabinette, 1871-1914, Sammlung der diplomatischen Dokumenten des Auswartigen Amts, hrsg. von J. Lepsius, A. Mendelssohn Bartoldy und F. Thimme, 1-40 vols, Berlin, 1922-1926. 
za juli 1914. Da bi preduhitrio Kauckog, Bilov je još u maju 1919. uveo posebnu indeksaciju u arhivu spoljnih poslova podelivši sedam hiljada dokumenata na dve grupe - "odbrana" i "optužba". Odeljenje je potencijalno sav inkriminativni materijal izdvajalo i davalo natrag tvorcima: kancelaru Teobaldu fon Betman Holvegu, sekretaru Jagovu i drugima kao njihove "privatne papire". Ta rana faza prikrivanja bila je dogovorena još 7. januara 1919. kada je predsednik komisije za primirje Erzberger sazvao predstavnike ministarstava inostranih poslova i vojske da dogovore aktivnosti. Bilov je tada određen za rad na diplomatskim izvorima, a nekadašnji Ludendorfov blizak saradnik major Fon Harbou (Bodo von Harbou) za rad na vojnim. Njihov zadatak je bio da građu tako odaberu da pokažu da se "Antanta dugo i sistematično pripremala za rat protiv Nemačke" i da ona, a ne Nemačka, snosi direktnu odgovornost za izbijanje rata $1914 .{ }^{66}$

U januaru 1920. tadašnji ministar inostranih poslova Miler (Müler) u privatnoj prepisci je definisao na sledeći način zadatke: „Naš zadatak može biti samo to da se, ne svakog dana ili što češće, ukazuje na to da nije krivica samo na nama", a na drugoj strani prosvećivanje naroda. Bilov je predlagao brošure popularnog karaktera. ${ }^{67}$

Sledeća etapa bilo je formiranje "Radnog odbora nemačkih udruženja" u aprilu 1921, koji je prvenstveno imao za cilj domaću publiku. Međutim, $u$ isto vreme formirano je telo „Centralna služba za istraživanje uzroka rata" (Zentralestelle für Erforschung der Kriegsursachen) koje će delovati do 1937. godine. Na njeno čelo će 1923. doći Alfred fon Vegerer, bivši oficir i učesnik rata. Kako je trebalo delovati prema inostranstvu, pokrenut je mesečnik Die Kriegsschuldfrage čiji je prvi broj izašao u julu 1923. Već tada je određen cilj da se za nemačke poglede pridobiju krugovi u SAD-u, a potom u Velikoj Britaniji, manje tvrdi prema Nemačkoj od Francuske. Među prvim akcijama je bilo dokazivanje da su i Francuska i Rusija u leto 1914. bile spremne za rat. ${ }^{68}$ Drugu oblast delovanja su predstavljali Sarajevski atentat i

66 Holger H. Herwig, "On Man and Myths. The Use and Abuse of History and the Great War", The Great War and the Twentieth Century, Jay Winter, Geoffrey Parker, and Mary R. Habeck (eds), Yale University Press, 2002, str. 301-303; Isti, Clio Deceived. Patriotic Self-Censorship in Germany After the Great War, str. 92-93; Osnovne informacije: В. Буха, н. Д., стр. 21.

67 M. Dreyer, O. Lembcke, n. d., str. 215 (navedeno kod: В. Буха, н. Д., стр. 22, нап. 24).

68 Uprkos skrivanju i čišćenju građe, istoričari upravo navode brojne onovremene kompetentne iskaze koji dokazuju suprotno od tadašnjih političkih želja revizionista. Drugog jula vojska je presirala na rat tvrdeći "sada 'sa Rusijom koja još nije spremna' i Francuskom 'veoma preokupiranom domaćim problemima i finansijskim 
austrougarsko-srpski odnosi pred rat. Od januara 1930. počeće da izlazi list pod nazivom Berliner Monatshefte. ${ }^{69}$

Intenzivno je nastavljena akcija "prikrivanja” otpočeta još za vreme Svetskog rata tokom diplomatske akcije u julu 1914, a potom objavljivanjem nemačke Bele knjige. Uvek se tvrdilo da se radi o "opkoIjavanju Nemačke", a u isto vreme je Austro-Ugarska podsticana na nepomirljivost i prvi korak. Tako je moglo izgledati da je ulazak u rat bila čista iznuda, a ne namera. Kasnije, predstavnici tradicionalne elite nastojali su da sakriju svoju ulogu u izazivanju teškog i izgubljenog rata. ${ }^{70}$ Zato su se za javnost smišljali i puštali glasovi da je pitanje o ratnoj odgovornosti upereno protiv zemlje, države, otadžbine, da treba moralno spasavati Nemačku i da je to patriotska dužnost svakog Nemca. ${ }^{71}$

Kao u svim velikim epohama, pre građe i profesora pojavljuju se memoari. U ovom slučaju oni su prava slika namernog prikrivanja. Pojavili su se tako "stilizovani" memoari Betman Holvega (1919), feldmaršala Fon Hindenburga (1920), generala Moltkea (1922), admirala Tirpica (1919), nešto kasnije Bilova (1930), i samog kajzera (1922). Tako je na primer kajzer u sećanjima tvrdio da u Potsdamu nije držan Krunski savet 5. ili 6. jula, što se inače tvrdilo u javnosti. To je bilo utoliko tačno što se telo formalno nije sastalo, ali je kajzer prećutao da je u ta dva dana pojedinačno primio sve najmerodavnije političke i vojne

potresom'; Wilhelm II je odlučno uveravao svog ministra vojnog Falkenhajna (5. VII) i delegata admirala Tirpica (6. VII) da ruska intervencija nije verovatna jer "Car neće dati svoju podršku kraljeubicama i jer je Rusija u ovom trenutku vojno i finansijski totalno nepripremljena za rat". Saksonski i bavarski vojni atašei u Berlinu prenosili su isto: „Načelnik Generalštaba je rekao 'da nikad nećemo dobiti takvu dobru priliku kao sada na račun francuske i ruske nekompletirane armije"' (V. R. Berghan, Germany and the Approaching of War in 1914, St. Martin Press, New York, 1973 (1993), u prvom izdanju str. 188, 189, 203). Videti takođe paletu istih procena da je Nemačka još sposobna i u boljoj situaciji od Rusije i Francuske bar do 1916. ili 1917. kod: Annika Mombauer, Helmut von Moltke and the Origins of the First World War, Cambridge University Press, 2001, (2003, 2005), prema poslednjem izdanju str. 177, 178, 180, 185-187, 189-190, 194-195, nap. 44. O ruskoj nespremnosti kao razlogu za suzdržanost pišu: V. Artamonov (videti nap. 30) і В. Штрандман, $\boldsymbol{H}$. д., стр. 307, 309, 318.

69 В. Буха, Н. Д., стр. 25.

70 Bivši kancelar Betman-Holveg (T. von Bethmann Hollweg), sekretar za spoljne poslove Jagov (Gotlieb von Jagow) i visoki funkcioner u istom ministarstvu Stum (Wilhelm von Stumm) povezali su se i dogovorili kako da se brane ako dođe do sudskog procesa. Štum ih je uputio koja su najkompromitujuća akta čiji je sadržaj veoma optužujući za Nemačku i njih lično treba skloniti (A. Mitrović, "Fric Fišer ili nemačko suočavanje sa istorijom", uvodna studija, u: Fric Fišer, Savez elita, Nolit, Beograd 1985, str. 20).

71 A. Mitrović, n. d., str. 15-20. 
ličnosti radi savetovanja o budućem ratu. Ili kada se u memoarima tvrdilo da nemačka vlada nije znala za austrougarski ultimatum pre večeri 23. jula, i to je formalno tačno, jer se vlada nije sastajala, ali su car, kancelar, državni sekretar za spoljne poslove, šef generalštaba i mnoge druge ličnosti, uključiv i nemačkog ambasadora u Beču, znali za ultimatum, bili upućeni u suštinu njegovog sadržaja pre nego što je bio napisan i, najzad, dobili konačan tekst ovog dokumenta ranije nego vlada Srbije. ${ }^{72}$ Mada su, kako vidimo, mnogi dobijali službenu građu iz arhiva kako bi se zaturila, dosledno je nisu koristili. „Patriotski cenzori" su prečešljavali konačne tekstove i čistili ih. Kada je udovica Moltkea htela da objavi njegove papire vezane za izbijanje rata, preko drugog generala, jednog diplomate i više ostalih upozorena je da ih ne objavljuje. Kada su se ipak 1922. pojavili, nisu sadržali ništa o julskoj krizi. Voljni cenzor bio je Moltkeov stariji sin Viljem. Nešto je sačuvao mlađi sin Adam u prepisu, a supruga ličnu prepisku, koja je ostala njihovoj kćeri. Slično su prošli papiri feldmaršala Hindenburga, koje je kasnije držao njegov unuk Hubertus. Ali nisu samo tada čišćeni, čistio ih je 60-ih istoričar nacionalista Valter Hubač (Walther Hubatsch). ${ }^{73}$ Papire generala Ludendorfa držao je njegov zet koji je tvrdio da u njima nema ništa relevantno za Prvi svetski rat (sic!). Papiri Kurta Riclera, u julu 1914. starijeg savetnika Betman Holvega, objavljeni su tek 1972. Kada je on umro 1965, a njegova sestra razmatrala mogućnost objavljivanja, drugi brat je uništio njihov veći deo. Ostatak je sredio istoričar Diter Erdman i kao takvi su dati u Federalni arhiv u Koblencu sa osmogodišnjim embargom. Na kraju, isti istoričar in je objavio. Međutim, afera se tu nije završila. ${ }^{74}$

Ta nevidljiva "patriotska cenzura" mnogo je činila da se pojedini dnevnici i memoari uopšte ne objave. ${ }^{75}$ Nisu bez pritisaka, opstrukcije

72 Isto, str. 20-21.

73 Hubač je u jednom svom radu iz 1958. koristio dnevnike admirala G. A. fon Milera, ali tako da je izbegao sve što se navodi o agresivnim težnjama nemačkog vođstva (A. Mitrović, n. d., str. 35).

74 K. D. Erdmann (ed.), Kurt Riezler - Tagebücher, Aufsätze, Dokumente, Götingen, 1972, Na ove važne dnevnike oblak sumnje nadneo je 1983. nemački istoričar Bernd Sösemann otkrivši da su unosi za period jula 1914. pisani na drugoj vrsti papira a potom pridodati dnevniku kao umetak. To ga je navelo da pomisli da je Riezler možda ovo pisao nakon rata i da je preradio original (B. Sösemann, „Die Tagebücher Kurt Riezler", Historische Zietschrift, 1983, str. 327-369; navedeno kod: Volker R. Berghahn, Imperial Germany 1871-1914. Economy, Society, Culture and Politics, Berghahn Books, Oxford, 1994 (2005), prvo izdanje str. 287, nap. 21).

75 H. Herwig, n. d., str. 304-305; Isti, "Clio Deceived. Patriotic Self-Censorship in Germany After the Great War", Forging Collective Memory. Governments and International Historians through Two World Wars, Keith Wilson (ed.), Berghan, Oxford, 1996, str. 87-127; Annika Mombauer, Helmut von Moltke and the Origins of 
i autocenzure mogli proći ni memoari nemačkog ambasadora u Londonu (1912-1914) kneza Lihnovskog (K. M. F. Lichnowsky). Bio je svedok opstruiranja mira i po povratku je objavio jednu brošuru 1916. u kojoj je to izložio. Izbegao je hapšenje koje su neki predlagali. Tek 1927. objavio je u Drezdenu memoare, u kojima je priložio svoje memorandume o nemačkoj odgovornosti, ali ovog puta ublažene. Umro je 1928. napadan i usamljen. ${ }^{76}$

Pridobijanje Amerike za reviziju vođeno je različitim kanalima. Težište je bilo na pridobijanju američkih naučnika, ali jednako se nastojalo pridobiti i političke aktere koji bi u institucijama otvarali to pitanje $\mathrm{i}$ animirali medije. Treći način je bilo pokrivanje prostora radio-programima, slanje časopisa i knjiga bibliotekama, slanje ličnosti iz Nemačke, učešće na naučnim skupovima, ostvarivanje uticaja na izdavanje dokumentacije, bibliografija i dr. Na ovom poslu radila je celokupna nemačka konzularna i diplomatska mreža u SAD-u. Nemačke predstavnike je posebno zanimalo da se promoviše pogled da su koreni rata stariji, u prvom redu ruska težnja za kontrolom tesnaca i francuska za povratkom Alzasa i Lorene. Trebalo je, po rečima Vegerera, otkloniti te „bazične greške o navodnom 'blanko čeku' Austriji i važnosti pokušaja posredovanja Edvarda Greja", insistirati na pozadini Sarajevskog atentata (krivica Srbije i Rusije) te povezanosti ruske mobilizacije sa objavom rata. Procena ove aktivnosti je polazila od činjenice da u zemljama čije vlade zavise od javnosti glavni cilj postaje pridobijanje javnog mnjenja. Prema nemačkom ministarstvu „prosvećivanje javnog mnjenja u bivšim neprijateljskim i neutralnim zemljama je suštinski, bazični zadatak za postizavanje revizije mirovnih ugovora". ${ }^{77}$

O aktivnostima nemačkog ministarstva inostranih poslova na „prosvećivanju" američkih istoričara u korist nemačkog viđenja prvi je istraživački pisao Emanuel Gajs, a potom mnogi istoričari, uključujući američke. ${ }^{78}$ Prvi istoričar kome je sa nemačke strane poklonjena pažnja

the First World War, Cambridge University Press, (2001, 2003), 2005, str. 6-7, (sudbina ostavštine od 1916. do 1993); videti takođe: Sacha Zala, Geschihte unter der Schere politicher Zensur. Amtliche Aktensammlung im internationale Verglech, München, 2001.

76 A. Mitrović, n. d., str. 26-27.

77 Herman Wittgens, "Senator Owen, the Schuldreferat, and the Debate over War Guilt in the 1920s", Forging Collective Memory. Governments and International Historians through Two World Wars, Keith Wilson (ed.), Berghan, Oxford, 1996, str. 129, 137.

78 I. Geiss, "The Outbreak of the First World War and German War Aims", 1914: The Coming of the First World War, Walter Laqueur and Georgge L. Mosse (eds), Harper Torchbook, New York, 1966; Warren I. Cohen, The American Revisionists: The Lessons of Intervention in World War I, Chicago, 1967; Ellen L. Evans and Joseph O. 
bio je Hari Barns, koji je svoje revizionističke poglede objavljivao u: Current History, American Historical Review i dr. a 1927. objavljuje i knjigu. ${ }^{79} \mathrm{U}$ tri navrata je pozivan u Nemačku $(1926,1927,1929)$, i tom prilikom je bio upoznat sa nekadašnjim nemačkim carem, Bertholdom, A. Cimermanom i drugima. "Referat" je kupovao i distribuirao njegovu knjigu prevedenu na nemački i francuski. Samo u Parizu, nemačka ambasada je podelila 150 primeraka. Slično su distribuirani i njegovi članci širom sveta. Barns je svoje interesovanje otkrio čitajući članke istoričara Sidnija Feja (Sidney Fay) u časopisu American Historical Review u kojima je doveo pobedničku tezu u pitanje te izložio shvatanje o podeljenoj odgovornosti. Kada je konačno izašla Fejova knjiga, $1928,^{80}$ Referat se odmah zainteresovao, otkupio veliki broj i poslao u 57 nemačkih ambasada i konzulata, a francusko izdanje na još 31 mesto. Fejova veza sa Referatom nije išla preko Vegerera nego istoričara Hermana Luca (Hermann Lutz). On je upozorio Nemce da Barns gubi na ugledu u SAD-u, mada je Barnsova šokantna knjiga "pogurala" interesovanje i za Fejovu. Kada se pročulo da američki istoričar Bernadot Šmit (Bernadotte Schmitt) priprema knjigu na istu temu, ${ }^{81}$ a poznajući njegove ranije uništavajuće kritike Barnsove i Vegererove knjige, Luc pokušava (1928) sve da ga tokom njegovog boravka u Berlinu nagovori da odloži objavljivanje jer će uskoro biti dostupni novi izvori. Nemac ne uspeva i usput saznaje da je već dogovoreno francusko izdanje. Bio je to udarac za Referat. Međutim, Fej javlja Lucu da je Smit doživeo dosta kritika u SAD-u, ali i mnogo veću podršku, pa i Pulicerovu nagradu i nagradu Džordž Luis Bir.

Referat je, uz saradnju konzularne službe i ambasade, neprestano sugerisao koji su novi istoričari vredni pažnje te preporučivao delatnost u institucijama i udruženjima. Na primer dr Karla Vitkea (Carl Wittke), Tomasa Vertebejkera (Thomas Jefferson Wertenbaker), šefa katedre na Prinseton univerzitetu, profesora Majkla Hermon Korana (Michael Hermond Cohran) sa Univerziteta Misuri. Za sve njih

Baylen, "History as Propaganda. The German Foreign Ministry and the 'Enlightenment' of American Historians on the War-Guilt Question, 1930-1933", Forging Collective Memory. Governments and International Historians through Two World Wars, Keith Wilson (ed.), Berghan, Oxford, 1996, str. 150-177; A. Mitrović, "Fric Fišer ili nemačko suočavanje sa istorijom", uvodna studija, u: Fric Fišer, Savez elita, Nolit, Beograd, 1985, str. 9-53.

79 H. E. Barnes, The Genesis of the World War, New York, 1927. Barnes (1889-1968) je objavljivao u New Republic, u Berliner Monatheften koji je štampan na engleskom. Predavao je na koledžu Smit (Smith College, Massachussets) (1923-1929).

80 Sidney Fay, The Origins of the World War, New York, 1928.

81 Bernadotte Schmitt, The Coming of the War: 1914, New York, London, 1930. 
saradnici su predlagali kako se mogu pridobiti za nemačku stvar, od finansijske podrške do počasti, karata za pozorišta, prijema i sl. Uprkos pokušajima, Nemci nisu mogli biti zadovoljni. Koranova knjiga nije mogla demantovati Smita.

Pa ipak uvek je iskrsavalo po neko novo ime. Konzul iz Njujorka je obaveštavao 1931. da su pored Feja, među umerenima, profesor Sontag sa Prinstona, koji je u najnovijoj knjizi iz diplomatske istorije Evrope tvrdio da je nemoguće odrediti odgovornost za rat. Tu su Vilijam Langer (William L. Langer) sa Harvarda, Parker T. Mun (Moon) sa Kolumbije, mladi ekspert Oron J. Hejl (Hale) sa Virdžinije, Ralf Luc (Ralph Lutz) ${ }^{82}$ sa Stanforda i Robert Binkli (Binkley) sa Vestern univerziteta. Čvrsto na nemačkim tvrdnjama stajali su i dalje Barns i Koran. ${ }^{83}$ Sa druge strane, Vegerer je apostrofirao bivšeg urednika časopisa American Historical Review, profesora Džejmsona (J. F. Jameson) pod kojim je revija imala razumevanja za revizionizam, takođe profesore Lingelbaha (W. E. Lingelbach) sa Pensilvanije i Ševila (F. Schevill) sa Univerziteta Čikago koji su branili revizionizam u raznim publikacijama. Među mlađima, šef Referata je video kao korisne Helmrajha (E. C. Helmreich) i Tansila (C. C. Tansill). Posebno je bio uvažavan Čarls Tansil koji je pomagao senatoru Robertu L. Ovenu da otvori pitanje ratne krivice u američkom Senatu 1926. i svojim radovima u listu Monatshefte "jasno izložio koncepciju ratne krivice (...) u našu korist". ${ }^{84}$

Francuski istoričar Renuven je objavio analizu u kojoj je tvrdio da je od 215 upitanih američkih istoričara svega njih osam bilo čvrsto uvereno u isključivu krivicu centralnih sila, 99 je verovalo da je pretežna odgovornost na centralnim silama. Po njemu to se moglo pripisati usredsređenom nemačkom naporu da utiče na američko javno mnjenje. ${ }^{85}$

Od 1936. Monatshefte nije smeo više štampati radove američkih istoričara. Tako se privremeno završila priča o saradnji. ${ }^{86}$

U nemačkoj politici prema SAD-u ambicije su dosezale ne samo do profesora, senatora, lokalnih političara, javnog mnjenja preko medija, popularnih i naučnih knjiga, već je postojala evidentna

82 Trebalo je da piše predgovor engleskog izdanja Ćorovićeve knjige.

83 E. Evans, O. Baylen, n. d., str. 168-169.

84 Isto, str. 165; Herman Wittgens, "Senator Owen, the Schuldreferat, and the Debate over War Guilt in the 1920s", str. 136.

85 Pierre Renouven, "Les Historiens americains et les responsibilites de la guerre", Revue des Deux Mondes, II, 8 (15 avril 1931), str. 886-903 (navedeno kod: E. Evans, O. Baylen, n. d., str. 155).

86 E. Evans, O. Baylen, n. d., str. 170. 
ambicija da se počne uticati na školske udžbenike. Neki koraci su preduzimani, posebno kod univerzitetskih, ali su konzuli upozoravali Referat da bi agresivan rad mogao izazvati podozrenje. Trebalo je raditi u "rukavicama". Da bi se sa odabranim licima stupilo u kontakt te izbeglo podozrenje vlasti, korišćeni su njihovi prijatelji i kolege.

Svemu tome davala je otpor "stara garda" američkih profesora koja je aktivno učestvovala u ratnoj propagandi tokom rata ili se nosila sa nemačkim delegacijama u Parizu i na drugim konferencijama.

\section{Odnos prema krivici za rat i publikovanju relevantne građe u Austriji}

U Austriji je posle rata, od 1919, preovladalo mišljenje da oko predmeta ne treba otvarati raspravu jer je to stvar "Austrougarske monarhije", a ne Austrije. Kada je u Senžermenskom ugovoru određena krivica za rat, ni tada nije bilo spremnosti da se ide u obaranje takvog akta. Osporavanje krivice je postalo stvar nekolicine aktera na stranicama pomenutih nemačkih revija koje su se time bavile. Tu je posebno aktivan bio general Edmund fon Glajse-Horstenau, ali ponajviše dr Hans Ibersberger i dr Ludvig Bitner. Poslednji će biti pobornik Anšlusa i vatreni obožavalac Hitlera kao "najvećeg Austrijanca”. Kada je Roderik Gos (Roderich Gooss) u decembru 1918. godine krenuo da priprema jedan korpus građe za objavljivanje, nije bio načisto da li je to naučni ili politički poduhvat. ${ }^{87}$ Smatrao je za veliki nedostatak nedostupnost papira grofa Hojosa (Count Alexandar von Hoyos), šefa kabineta grofa Bertholda u Berlinu jula $1914 .^{88} \mathrm{U}$ Austriji je nastalo mišljenje da bi objavljivanje materijala moglo da bude veliko svođenje računa sa vojskom, ratnim huškačima i profiterima koji su činili ekstremnu desnicu austrijske politike. Kada je rad u junu 1919. bio gotov, Oto Bauer (Otto Bauer), ministar inostranih poslova Austrije, bio je protiv njegovog objavljivanja u Berlinu i uspeo je da to spreči. Smatrao je da bi neprijateljima time omogućili dokaz da je sve bilo nemačka

87 Gos je trebalo da uradi dodatak austrougarskoj Crvenoj knjizi iz 1914.

88 Hoyos je objavio svoju stilizovanu verziju Der deutsch-englische Gegensatz und win Einfluss auf die Balkanpolitik Osterreich-Ungarns, Berlin, 1922, a njegove beleške istoričar F. Fellner u prilogu svog članka "Die 'Mission Hoyos'", u: Velike sile i Srbija pred Prvi svetski rat, ur. Vasa Cubrilović, Beograd, 1976, str. 387-410 (dodatak: A. Von Hoyos, Personliche Erinnerungen an die Schreckenstat in Sarajevo und den Ausbruch des Weltkrieges, str. 411-418). Ove radove temeljno je koristio Andrej Mitrović. 
intriga i to upravo pred odluku o miru. Jedino ako Nemačka odbije potpis ugovora, imalo bi nekog smisla objaviti to u Beču. Ako Nemačka potpiše, objavljivanje bi samo otežalo položaj Austrije. ${ }^{89}$

U svakom slučaju, u pripremi za konferenciju mira delegacija je imala instrukcije da ne negira odgovornost Monarhije za izbijanje rata "od ultimatuma Srbiji 'koji otkriva namere da se ide u rat' do (negativne) reakcije na pokušaje posredovanja Edvarda Greja, ali mora biti rečeno sa naglaskom da taj režim koji je odgovoran za rat nije bio nemačko-austrijski već režim Austrougarske monarhije čije je Ministarstvo inostranih poslova kontrolisala mađarska klika". U pogledu Mađara su bili jasni, a u pogledu nemačke krivice su dali instrukcije da se bude elastičniji: „Ako neko moguće kaže da je Nemačka gurala AustroUgarsku ispred to je pogrešno, i može biti potvrđeno dokumentima (...) može se saopštiti da Nemačko-austrijska vlada je odlučna da publikuje dokumenta i da je rad u toku, ali još nije završen." ${ }^{\prime 90}$

Ipak pogledi su se promenili. U junu 1926. na inicijativu direktora Državnog arhiva dr Ludviga Bitnera i odlukom vlade započeo je rad na prikupljanju i odabiru diplomatskih dokumenata za period 1908-1914. Izdato je 1929-1930. osam tomova građe (11.200 dokumenata). Finansijski i ideološki, rad je bio podržan iz Nemačke. Bitner je u Berlinu diskutovao stvar sa urednikom nemačkog izdanja Timeom (Friedric Thimme). Ceo rad se odvijao u punoj diskreciji. Čak su i tipografi bili obavezni na diskreciju kada je u aprilu počelo štampanje. ${ }^{91}$ Svoju žurbu i "časni dug" austrijski profesori i državnici su objašnjavali trendom u svetu (pripreme građe u Britaniji, Francuskoj, Italiji) ${ }^{92}$ i mogućnošću da zemlje naslednice posle isteka embarga krenu sa objavljivanjem bečke

89 Ulfried Burz, "Austria and the Great War: Official Publications in the 1920 s and 1930s", Forging Collective Memory. Governments and International Historians through Two World Wars, Keith Wilson (ed.), Berghan, Oxford, 1996, str. 181-183. Pored savezničkih misija jedini pristup arhivu su imali Gooss, Henrich Früdjung (čuveni) i A. F. Pribam.

90 Ulfried Burz, n. d., str. 182.

91 „Аустријска спољна политика од анексије до светског рата”, Политика, 17. 12. 1929. Radi se o: Österaich-Ungarns Ausspolitik von der bosnichen Krise 1908 bis zum Kriegsausbruch 1914, hrsg. von L. Bittner und H. Übersberger, Wien, 1929 (1930). Za Srbiju, odabir dokumenata je radio bečki profesor Hans Ibersberger. On je napisao i predgovor.

92 Zbirke dokumenata koje su sledile u ovim zemljama takođe su nosile znakove izvesne selektivnosti provocirane "višim" državnim interesom, jer su neka pitanja imala aktuelni značaj kao i neki skriveni aktuelni interes u svetu kolonija ili Kine (videti šire: Keith Wilson (ed.), Forging Collective Memory. Governments and International Historians through Two World Wars, Berghan, Oxford, 1996). 
građe već 1930 (1940). ${ }^{93}$ Još dok nije postao direktor, Bitner je izvestio kancelara da su, prema registru, pokradena dokumenta Bosanskog odeljenja bivšeg ministarstva finansija „koja su mogla pokazati da je srpski poslanik u Beču Jovanović upozorio dvor pre puta u Sarajevo". ${ }^{94}$

Tadašnji kancelar Skober (Scober) uputio je 19. novembra 1929. cirkularno pismo-instrukciju misijama u inostranstvu kako se nadalje ima propagirati i govoriti o uzrocima rata posle objavljivanja građe: „Konačno, publikovana građa donosi još više dokaza da su Austro-Ugarska i Nemačka, čak i posle raskida sa Srbijom, ozbiljno radile da lokalizuju rat i činile sve da zadrže Bugarsku i Tursku da ne napadnu Srbiju, i štaviše permanentno su nudile garantije za očuvanje Srbije kao suverene države, čak i nakon njenog poraza, sve dok svi ovi pokušaji za lokalizacijom nisu propali kao rezultat prevremene ruske mobilizacije. ${ }^{\prime \prime 5}$

Ohrabren izdavanjem diplomatske građe, Ibersberger je pisao o Solunskom procesu, ${ }^{96}$ na kome je suđeno jednom od "organizatora" atentata u Sarajevu. Sarkotić je priredio knjigu o procesu u Banjaluci. Fricu Rejnehlu (Fritz Reinöhl) je Ministarstvo inostranih poslova poverilo da napiše knjigu o pansrpskim intrigama pre i nakon izbijanja rata. Knjigu je objavio Bečki arhiv 1944. Kao što je u srpskoj istoriografiji već bilo poznato, Ibersberger, Bitner i Alojz Hajek su objavili knjigu Srpska spoljna politika 1908-1914. (1945) na osnovu zaplenjene građe 1941. Istoričar Burc navodi da je ostala misterija šta je sa trećim tomom druge serije za period od 26. maja do 6. avgusta 1914. koji je štampan u nekoliko primeraka. ${ }^{97}$

Vojna građa, koja je kasnila za diplomatskom, bila je takođe tendenciozno selektovana kako bi podržala legendu o feldmaršalu Konradu. Pojedini priređivači, kao major Ratzenhofer, toliko su preterali da je prvi tom Austrougarskog poslednjeg rata 1914-1918. morao biti povučen. Pa ipak, pod kontrolom maršalovih biografa Kizlinga i Glajzea fon Horstenaua, tomovi su izlazili u istom duhu do $1938 .{ }^{98}$

Istoričar mora da zapazi da je učinjen veliki otklon u odnosu na prve dane postojanja Republike Austrije. Tada, u prvoj izjavi

93 Čehoslovačka je imala pravo da počne 1930, a Poljska, Rumunija i Jugoslavija 1940. godine.

94 Ulfried Burz, n. d., str. 185.

95 Isto, str. 188.

96 Ibersberger je napisao dugačak uvod za nemački prevod (Berlin, 1933) srpskih dokumenata o procesu Tajna prevratna organizacija, Solun, 1918.

97 Ulfried Burz, n. d., str. 188.

98 H. Herwig, n. d., str. 308-309. 
novog ministra inostranih poslova Ota Bauera, u zgradi "Balhausplac", novembra 1918, prisutni su bili opomenuti da se nalaze "u prostorijama u kojima je bio spremljen zločin svetskog rata". ${ }^{99}$

\section{Današnje stanje stvari}

Tokom 90-ih i u prvoj deceniji 21. veka objavljeno je više važnih knjiga, članaka i tematskih zbornika koji tretiraju ovu tematiku. ${ }^{100}$ Skrećemo pažnju samo na one koje uže tretiraju ili preispituju povode i uzroke izbijanja ovog rata, a ne njegovo celokupno trajanje i forme. Zahtevalo bi daleko više prostora osvrnuti se na sva nova ili neka dopunja izdanja koja dnevno izlaze. Svi radovi imaju po jedno poglavlje ili deo posvećen „julskoj krizi 1914" ili „Sarajevu 1914”. Autori se tu oslanjaju na ona tumačenja koja su njima bliska iznoseći često jedan standardni set najpoznatije litarature.

Uopšteno, moglo bi se tvrditi da su u proteklih dvadeset godina opstala tri već poznata trenda, jedan koji je etablirala nova istoriografija primarno u Nemačkoj i Austriji oko imperijalnih korena, prvenstveno

99 В. Буха, н. д., стр. 26, нап. 32 (prema: Edmund von Glaise-Horstenau, „Neuösterreich und die Kriegsschuldfrage", Berliner Monatshefte, 1 (1930), str. 1-4.

${ }^{100}$ R. J. W. Evans and Hartmuth Pogge von Strandmann (eds) The Comming of the First World War, Clarendon Press, Oxford, 1991; Samuel R. Williamson, Austria-Hungary and the Origins of the First World War, New York, 1991; John W. Langdon, July 1914: The Long Debate, 1818-1990, Berg, New York/Oxford, 1991; V. R. Berghan, Germany and the Approaching of War in 1914, St. Martin Press, New York, 1973 (1993); Holger H. Herwig, The First World War Germany and Austrian-Hungary 1914-1918, Arnold, 1997; Annika Mombauer, The origins of the First world war, Controversies and consensus, Longman, 2002; Ista, Helmut von Moltke and the Origins of the First World War, Cambridge University Press, 2001, 2003, 2005; Keith Wilson (ed.), Decisions for War, 1914, St. Martin's Press, New York, 1995; Keith Wilson (ed.), Forging Collective Memory. Governments and International Historians through Two World Wars, Berghan, Oxford, 1996; Richard C. Hall, The Balkan Wars 1913-1913 Prelude to the First World War, Routledge, 2002; Richard F. Hamilton, Holger H. Herwig (eds), The Origins of World War I, Cambridge University Press, 2003, 2007; Rut Henig, The Origins of the First World War, (3th ed.), Routledge, 2003, (1. izdanje 1993); David Fromkin, Europe's Last Summer: Who Started the Great War in 1914?, New York, 2004; James Joll \& Gordon Martel, The Origins of the First World War (3th ed.) Longman, 2007; Jay Winter, Geoffrey Parker and Mary R. Habeck, The Great War and the Twentieth Century, Yale University Press, 2002; Jay Winter, Antoine Prost, The Great War in History: Debates and Controversies, 1914 to the Present, Cambridge University Press, 2005; Sean McMeekin, The Berlin-Baghdad Express. The Ottoman Empire and Germany's Bid for World Power 1898-1918, Penguin, London, 2010; Sean McMeekin, The Russian Origins of the First World War, The Belknap Press, Harvard, 2011; Christopher Clark, Sleepwalkers: How Europe Went to War in 1914, Allen Lane, Penguin, London, 2012. 
nemačke težnje da se izvrši nova preraspodela moći; drugi, umereni konzervativizam koji respektuje nova otkrića, ali želi da ukaže na meru ugroženosti same Nemačke i Austro-Ugarske u "skoroj budućnosti” i koje su sledstveno bile prisiljene na "preventivni rat"; i treći, koji želi da ceo problem izbijanja rata suzi na Balkan, koji je počev od 90-ih po treći put u jednom veku postao paradigma za sve probleme sveta i osnovni deo medijsko-propagandnih satanizacija. Ako bismo širili temu, mogli bismo uočiti da postoje i drugi trendovi. U prvom redu tu su novija teorijska i primenjena razmatranja nacionalnog i nacionalnih identiteta sa definisanjem "starih", "novih" i „zakasnelih" nacija, potom ceo lanac različitih interesa za teme "sećanja”, "masovnog stradanja”, „ekonomije”, "migracija”, , "istorije polova” i dr.

Pišući o istraživačkim rezultatima nemačkog istoričara Frica Fišera, njegovim knjigama Posezanje za svetskom moći, Savez elita i dr., istoričar Andrej Mitrović je istakao da je Fišer svojim produbljenim istraživanjima doveo u pitanje tri dogme nemačke nacionalne svesti koje su se uspostavljale od Sarajevskog atentata pa u celom međuratnom periodu. Prva dogma je da je Rajh od 1914. do 1918. vodio odbrambeni rat, štaviše da je to bila "borba za opstanak". Druga dogma - da Rajh nije izazvao Prvi svetski rat. Treća dogma kojoj su dve prethodne služile za podlogu - da je nacistički rajh, dakle i nesporno nemačko izazivanje Drugog svetskog rata, nešto nesaglasno celoj ranijoj nemačkoj istoriji, nešto što je izuzetak, slučajnost. ${ }^{101}$

Fišer je ustanovio da je postojala težnja za postizanjem svetske moći sa odgovarjućim ciljevima koji su se zavisno od uslova menjali, ali ne bitno (Imperium Germanicum). Sa svojim saradnicima, Gajsom na prvom mestu, ustanovio je sve aktivnosti koje su vodile jedinom "rešenju" kako se ne bi propustila šansa da se atentat iskoristi kao povod za rat. Kroz knjigu Savez elita pokazao je da se osnovni cilj spoljne politike - svetska dominacija - nije promenio od 1871. do 1945. Konzervativci su tokom rasprava sa njim ponešto ublažili međuratne stavove. Na jednoj strani su odgovornost pripisali grupi oko generala Ludendorfa i pangermanistima, a ostale su amnestirali, a na drugoj strani, počeli su uvoditi kategorije kao "preventivni rat", "uračunati rizik" ili "polikratski haos" (profesori Andreas Hillgruber i Wolfgang Mommsen). Početkom 80-ih očevidno nije moglo da se istrajava na starom mitu u celini, pa su se njegove sastavne teze počele pojavljivati u novim formama. Sam Fišer je ostao u trajnoj diskusiji (borbi) iz dubokog uverenja da se ta prošlost i te kako tiče Nemaca, nemačkih

${ }^{101}$ A. Mitrović, n. d., str. 15. 
suseda i celog sveta. ${ }^{102}$ Koliko je prizemnih udaraca morao ovaj borac da istrpi, slično profesoru Kantrovicu između dva rata. Pomenimo samo da je ministar spoljnih poslova Gerhard Šreder (Gerhard Schröder), postupajući po savetu starijih konzervativnih istoričara, Fišeru oduzeo sredstva koja mu je Gete institut dodelio za putne troškove za planiranu turu predavanja po Sjedinjenim Državama. Ovu turneju je doajen nemačkih istoričara Gerhard Riter (Gerhard Ritter) uporedio sa „nacionalnom tragedijom”. ${ }^{103}$

Profesor Berghan zaključuje da je posle mnogo godina rasprava među istoričarima oko odogovornosti za izbijanje rata u avgustu 1914, u toku kojih su nemački istoričari ili krivili Trojnu antantu ili sve podjednako za skliznuće u ponor, Fišerova kontroverza proizvela rezultat koji je danas široko prihvaćen u naučnoj zajednici koja se bavi neposrednim uzrocima rata - Carska palata u Berlinu gurnula je Evropu preko ruba. "Ti ljudi su nedelju dana pre 1. avgusta, zajedno sa jastrebovima iz Beča, svojevoljno pogoršali krizu, iako su bili u najpovoljnijoj mogućnosti da je primire i demontiraju." Sledeći naučne rezultate Fišera i sledbenika, može se, po Berghanu, konstatovati da postoji široki konsenzus da se tokom kritičnih nedelja najvažniji konflikt odvijao između vojnih i civilnih ličnosti Rajha. Krug oko Moltkea nije hteo da propusti priliku koja se ukazala "da se srede računi sa Antantom". ${ }^{104}$ Njegov austrougarski kolega je u periodu od 1 . januara 1913. do 1. juna 1914. godine 24 puta tražio rat protiv Srbije. ${ }^{105}$

Istoričar Džejms Džol (James Joll), u svojoj često navođenoj studiji o uzrocima rata, dodaje još jedan važan momenat - psihološki faktor ("the mood of 1914"), kao "krucijalni faktor" koji je stajao iza sunovrata Evrope u haos. Mada se ograđuje da se on može približno proceniti i da se razlikovao od zemlje do zemlje, od klase do klase, Džol zaključuje da je na svakom nivou postojala voljnost da se prihvati rizik ili prihvati rat kao solucija za čitav niz političkih, socijalnih i međunarodnih problema.

${ }^{102}$ Isto, str. 46, 47, 49.

${ }^{103} \mathrm{H}$. Herwig, n. d., str. 304.

${ }^{104}$ Volker R. Berghanh, $n$. d., str. 283. Berghan je dao lični doprinos svojim radovima o admiralu Tirpicu i radovima o militarizmu: Der Tirpitz Plan, 1971; Militarism: The History of an International Debate 1861-1979, 1981 (1984). Na istoj osnovi su radovi istoričara pruskog militarizma Gordona Krejga i u novije vreme Anike Mombauer (G. A. Craig, The Politics of the Prussian Army, Oxford University Press, 1955; Isti, Germany 1866-1945, Oxford University Press, 1978 (1981), prema drugom izdanju str. 302-338; A. Mombauer, n. d.).

${ }^{105}$ Dedijer, Sarajevo, str. 238. Ne uključujući period od 1906. do 1912, američki istoričar Fej je izračunao taj broj prema Konradovim kazivanjima. Konrad je težio da se južnoslovensko pitanje reši silom i preventivnim ratom protiv Srbije. 
Po njemu, valja se okrenuti i istraživanju mentaliteta evropskih vladara i njihovih podanika "jer će na kraju objašnjenje za uzrok rata tu ležati". Kategorije kao što su strah, napetost, frustriranost, nadanja masa da će im biti bolje, lepše, bogatije itd. treba uzimati u obzir. ${ }^{106}$ Istoričarima nije promakao taj faktor, ali su uočavali namerno proizvođenje masovne psihoze u određenom pravcu. Mediji su potpaljivali ratna raspoloženja na koja su vladajući "morali da odgovore". S druge strane, mediji su u Nemačkoj i drugim državama prećutkivali antiratne demonstracije, ništa manje masovne. Dehumanizacija neprijatelja, rasističke primese, insistiranje na "višim" i "nižim" civilizacijskim nivoima, "prirodnim pravima", "nemačkom kulturnom duhu" nasuprot "slovenstvu”, sve je to bilo deo "stanja duhova 1914" kada se lomilo - ići u rat ili smiriti krizu.

Uz istoriografiju kakva se etablirala decenijama kroz polemike, ali i uvođenje novih formi promišljanja i rada na izvorima, mi smo danas svedoci da postoje i neki drugi trendovi, manje naučni, a više odraz svog vremena. Rekli bismo dela sa političkom misijom. Istoričaru sa ovog prostora ne mogu da promaknu dela namenjena široj publici, kod globalnih izdavača, koja oživljavaju retoriku međuratne (poražene) Evrope. Nakon „kratkih istorija” Bosne i Kosova koje su političari delili novinarima i manje upućenim saradnicima, sada se, pred 100-godišnjicu pojavljuju dela koja "otkrivaju” dugo skrivanog krivca za rat - "srpski nacionalizam", "konspiraciju" protiv jednog uređenog i civilizovanog carstva koje je bilo nosilac progresa i stabilnosti na Balkanu. Otkriva se tako da je u korenu svega Garašaninovo Načertanije iz 1844, projekat "Velike Srbije", strast i sklonost za ubistvima vladara (1903, 1914) itd. ${ }^{107}$

Profesor Milorad Ekmečić je u više navrata upozoravao na mistifikacije koje su bile plod međuratnih rasprava o "ratnoj krivici”, a koje su postale baština nacionalnih i nacionalističkih ideologija. Jedan takav primer je olako baratanje interpretacijama Garašaninovog Načertanija. Projekat izrazito međunarodnog porekla, sa redakcijama državnika koje su imale povod da se saradnja sa Hrvatima prikrije pred Austrijom, počeo je u Nemačkoj i Austriji 30-ih da se ocenjuje kao početak "srpskog projekta". Izjednačilo se delovanje poverenika Narodne odbrane 1908-14. sa nekadašnjim aktivnostima Garašaninovih agenata koji su kontaktirali, uglavnom, sa istaknutim ličnostima. U drugoj nameri,

\footnotetext{
$106 \mathrm{~J}$. Joll, The Origins of the First World War, London 1984 (1996), prema prvom izdanju str. 196 (navedeno kod: V. Berghanh, n. d., str. 289).

${ }^{107}$ Christopher Clark, Sleepwalkers: How Europe Went to War in 1914, Allen Lane, Penguin, London 2012.
} 
da bi potkrepili ideju o dugom trajanju jugoslovenstva, srpski i jugoslovenski istoričari su mu takođe pripisali trajnost i permanentnost na putu ka zajedničkoj državi. ${ }^{108}$ Dokument, koji je evidentno ostao zaturen u Garašaninovim papirima i van operativne upotrebe do ponovnog otkrića i objavljivanja 1906, počeo se interpretirati ne samo kao izvor srpskog imperijalizma (hegemonizma) već i etničkog čišćenja u najnovijem vremenu. Posebno su teze austrougarskih nostalgičara bile podloga za pisanje o njemu u vreme NDH. Ovakvo razumevanje nastojaće danas da ožive neki istoričari u želji da krivicu za rat vide u srpskoj konspiraciji i ruskim težnjama. ${ }^{109}$ Jedna knjiga zavređuje da joj se posveti neka reč više budući da je namenjena ne samo naučnoj već i široj publici povodom obeležavanja 100 godina od izbijanja prvog iz serije velikih i uništavajućih ratova. Rata, koji je sve okrenuo naopako (iz ugla apologeta poretka do 1918).

Knjiga profesora Kristofera Klarka sa Univerziteta Kembridž, koja se pojavila prošle godine, već je izazvala pažnju, pohvale i kritike. Mora se odmah reći da je delo napisano vešto, a strukturom impresionira, kao i volumenom - 670 strana većeg formata. Međutim, već na prvom koraku, znalac će se suočiti sa problemom, umesto popisa literature, objavljene i neobjavljene građe, moraće da ide od napomene do napomene. Ako se na kraju seti svega, videće koja dela su zaobiđena. Međutim, tamo gde napomene impresioniraju navođenjem literature, stručnjak će se naći u čudu jer tekst ne odslikava tu šarolikost već je pre odraz tek jedne interpretacije, često medijskog preterivanja. Da bi na primer, efekat "krvave noći" 1903. i slika oficira bila što mračnija, daje se prvenstvo jednom izveštaju bečkog lista Neue Freie Presse od 12. i 13. juna. Da li je novinar bio maštovit ili je samo prenosio glasine čitalac neće saznati. U napomenama se navode dela Slobodana Jovanovića i Dragiše Vasića, ko ih je čitao zna da nema tih, dodatnih, užasavajućih

\footnotetext{
${ }^{108}$ Roderich Gooss, „Das osterreichisch-serbische Problem bis zur Kriegserklarung Osterreich-Ungarns an Serbien 28 Juli 1914", u: V. E. Fischer, V. Carl Bohm-Schön, Die Vorgeschichte des Krieges, 10, Berlin, 1930 (navedeno prema: M. Ekmečić, Ratni ciljevi Srbije, 2. izdanje, str. II). Posle njih javio se general Sarkotić, guverner Bosne tokom rata, u knjizi Der Banja Luka Prozess, 1, Berlin 1933. O novim instrumentalizacijama i pravom kontekstu Garašaninovog Načertanija videti: P. Љушић, Књига о Начертанију, Београд, 1993.

${ }^{109}$ M. Grmek, N. Đidara, N. Štimac (eds), Le nettoyage ethnique. Documents historigues sur une ideologie serbe, Paris, 1993, str. 57-80 (navedeno kod: D. Bataković, "Načertanije Ilije Garašanina: problemi i značenja", Dijalog povjesničara istoričara, 1, priredili Hans Georg Fleck i Igor Graovac, Zagreb, 2000, str. 109-125, nap. 32); Christopher Clark, n. d.
} 
detalja. ${ }^{110}$ Pominje se u napomeni izveštaj britanskog poslanika koji „izvlači fakta između glasina”, ali se ne navodi gde je ta razlika. ${ }^{111}$ I na samom početku knjige nailazimo na grešku, autora je neko pogrešno informisao da mesto ubistva još postoji - ondašnji Novi dvor, i on dalje vehementno nadograđuje priču (sic!). Nije mu poznato da je tzv. konak bio iza događaja porušen, a Novi dvor uskoro postao "stari". No to je sitnica, daleko krupniji stručni propusti su počinjeni. Uprkos navedenoj literaturi, on nastoji da ubedi čitaoce da je u Srbiji posle prevrata 1903. nastupila drastična promena i da su svi nesporazumi sa AustroUgarskom posledica te promene i preorijentacije na Rusiju. Ne zna ili neće da zna da je i kralj Aleksandar napravio taj preokret i da su gotovo svi političari prethodnog vremena nastavili da deluju i kasnije. ${ }^{112}$ Šta tek reći o razlozima za carinski rat ili aneksionu krizu? I tu je "krivica” do Srbije, ni slučajno u akcijama Austro-Ugarske. Klark neće da vidi da je postojala podela i među zaverenicima kada je npr. "topovsko pitanje" bilo na dnevnom redu, da je deo istaknutih zaverenika lobirao za nemačku i austrougarsku opciju. Teško će čitalac naći bilo šta od austrougarskih pa i bugarskih planova i nasrtaja u tom osetljivom vremenu kada je Srbija bila potpuno nespremna za ratna iskušenja i kada je samo primala pretnje. ${ }^{113}$ Ako nekih stvari nema, ima drugih. Pored Apisa, koji je glavni dizajner Sarajevskog atentata, tu je i Pašić, potpuno upoznat sa planovima. Ako je Pašić i bio svestan da Srbija mora da čuva mir i da ne izaziva sukobe, on je "podsvesno" radio da rat što pre izbije kako bi zaokružio nacionalni projekat. Za ovo, po Klarku, nisu potrebni ni izvori ni dokazi, on to realno pretpostavlja. Klark se takođe svrstao uz onaj trend, obnovljen 90-ih, koji začetak malignog velikosrpskog projekta vidi u pojavi Načertanija. Klark prećutkuje, ili ne zna da je Srbija već krajem avgusta 1914. izašla pred saveznike sa jugoslovenskim programom kao ratnim ciljem i da ga je u dogovoru

${ }^{110}$ I Vasić i Jovanović se oslanjaju na različita kazivanja (prepričavanja). Kod Vasića se navodi da je kralj pao od prvog metka, a Draga nakon desetog, a general Petrović od prvog. Pucala su svega četiri oficira čija su imena navedena. (D. Vasić, Devetsto treća, Odabrana dela, Beograd, 1990, str. 194-195). Jovanović je nešto "krvaviji" jer navodi da je u kralja ispaljeno trideset a u Dragu osamnaest metaka, te da je ona ubadana i sabljama te mrcvarena. Jovanović navodi kazivanje da nije postojala namera da se leševi bacaju nego samo pokažu trupama ali je Dragin ispao, pa je tek onda izbačen Aleksandrov (S. Jovanović, Vlada Aleksandra Obrenovića, Geca Kon, Beograd, 1931, str. 357).

${ }^{111}$ C. Clark, n. d., str. 4-5, 566-567, nap. 2.

${ }^{112}$ Klark je, kao i austrijski i nemački propagandisti između dva svetska rata, tvrdio zdravo za gotovo da su mnogi u Srbiji odbijali tu proaustrijsku politiku Obrenovića i da posle 1903. počinje antiaustrijski i proruski zaokret.

${ }^{113}$ Videti šire: М. Бјелајац, Дипломатија и војска. Србија и Југославија 1901-1999, Београд, 2010, стр. 25-64. 
sa predstavnicima Jugoslovena na zasedanju skupštine 7. decembra iste godine ozvaničila i borila se za njega. Za njega Garašaninovo Načertanije ostaje "blueprint” za srpske državnike sve do 1918.

Autor uporno insistira na 1903. da bi uspostavio kontinuitet sa antentatom iz 1914. Tako Apis i Pašić stupaju zajedno, sa sve Načertanijem. Svesni, po Klarku, da su srpski ciljevi pred Evropom toliko neprihvatljivi pa ih valja prikriti. Eto to je po ovom profesoru suština "konspiracije”. Za njega je nebitno što Evropa, gotovo unisono, prihvata oslobodilačku misiju balkanskih saveznika u ratu 1912/1913. ${ }^{114}$ Ta ista Evropa, izuzev Austro-Ugarske, bez protivljenja prihvata i Bukureštanski mir. Ah, ta Rusija koja sve to podržava! No Klark u zanesenosti ili neznanju zaboravlja da upravo Rusija savetuje balkanskim državama mir 1912. Autor umanjuje i prikriva rusku dezainteresovanost i povlačenje sa Balkana u jednom periodu u kome Austro-Ugarska upravo deluje vrlo ofanzivno. Ovde je Klark na istoj liniji sa istoričarem Mekmikinom, koji nastoji da ocrni francusko-rusku kombinaciju u julu 1914, konstruišući tezu da su Francuzi Rusima dali "blanc cheque”, prikazujući Sazonova kao ratnohuškača. ${ }^{115}$ Nešto pre Klarka i Mekmikina slične teze je lansirao američki profesor Džon Eti (John Etty). Dakle, srpski nacionalizam je stvarni uzrok Prvog svetskog rata. Uz Srbiju i Austro-Ugarsku, za rat je najviše kriva i Rusija jer nije Srbiju pustila niz vodu. ${ }^{116}$ Klarka podržava u toj tezi još jedan istoričar obrazovan na Kembridžu, Metju Prajs (Matthew Price), svojevremeno dopisnik BBC-a iz Beograda. On tvrdi da je Klark u pravu smatrajući da je pravda bila na strani Austro-Ugarske, kaže da se "previđa srpski drzak i bezosećajan odgovor na atentat (sic!)". ${ }^{117}$

Nije stoga čudno da Mekmikin podržava Klarkovo delo. Smatra da je knjiga obnovila primat Balkana u otpočinjanju konflikta, "uprkos donedavnom verovanju mnogih istoričara da je to pitanje bilo rešeno

\footnotetext{
${ }^{114}$ John Zametica, Book review on Christopher Clark, Sleepwalkers: How Europe Went to War in 1914, Allen Lane, London, 2012, neobjavljeni rukopis u posedu autora.

${ }^{115}$ Sean McMeekin, The Russian Origins of the First World War, The Belknap Press, Harvard, 2011, str. 56 (na knjigu i detalje skrenuo nam je pažnju John Zametica).

${ }^{116}$ John Etty, "Serbian Nationalism and the Great War", History Review, Mar 2009, Issue 63. "Historians tend to blame nationalism for the European ills which led to the outbreak of the Great War in 1914. They are able to cite many examples of German aggression, and coyly quote British sources to show that nationalism had even managed to affect our own view of the world. But, they assert, the brand of nationalism which did most to undermine international stability by 1914 was Serbian. Doubtless Emperor Franz Joseph of Austria-Hungary would have agreed."

117 Matthew Price, "Causes of First World War explored by Cambridge historian", (sajt http://www.thenational.ae/arts-culture/books/causes-of-first-world-war-exploredby-cambridge-historian, posećen 25. 4. 2013).
} 
na dobar način, uz konsenzus da je Nemačka htela rat iz svog straha od narastajuće Rusije". Po Mekmikinu, to je sterilna "nemačkocentrična ortodoksija". I on se "hvata" za krvave opise ubistva iz 1903. jer je to dokaz hipernacionalizma (a ne psihološke posledice trenutka u kome nastupa panika izvršitelja jer ne mogu pronaći kralja i kraljicu, a dovedene trupe misle još uvek da su tu da brane kralja - M. B.). Odaje priznanje Klarku da je srpsku zaveru u Sarajevu bazično korektno rekonstruisao nasuprot "istorijama koje su obojene 'ruskim kontra narativom"”. Klark je "pokazao", misli Mekmikin "da je austrougarski ultimatum bio daleko blaži nego onaj koji je NATO dao Beogradu pre kosovskog rata 1999", ali "da srpski odgovor nije ni najmanje bio pomirljiv, već 'visoko parfimisano odbijanje' pripremljeno da bi se impresionirala Francuska i Britanija dok je Rusija već dala podršku za rat". ${ }^{118}$ Podršku Klarkovom viđenju dao je na stranici Daily Mail-a Simon Grifit (Simon Griffith), koji vehementno poručuje da će posle superiorne knjige, i argumenata koji su u njoj izloženi, sav raniji konsenzus oko apsolutne nemačke odgovornosti biti bačen u kantu za otpad. ${ }^{119}$

Ipak, nisu svi tako oduševljeni delom Klarka. Najdžel Džons (Nigel Jones) podseća čitaoce da je dva puta potvrđivana nemačka odgovornost i puna volja da se atentat iskoristi kao povod za rat, što je javnosti otkriveno objavljivanjem građe iz Bavarskog arhiva na podsticaj Kurta Ejsnera, koga će nacionalisti zbog ovoga ubiti, a potom tu je sve što je izneo Fric Fišer i njegov krug. Džons pomalo ironično navodi "da budemo fer, Klark to ne negira. On zaobilazi provokativna pitanja o nemačkoj ratnoj krivici jednostavno ignorišući ih kroz skoro 700 stranica teksta. Ali kad Fišera i Gajsa konačno nevoljno pomene u zaključku on ih otera kao iritirajuće insekte." Zamera im što su pokušali da odgovornost pripišu samo jednoj državi! Najdžel Džons uzvraća Klarku kontraargumentom - zar nije jedna država kriva za Drugi svetski rat. Ili, još jednom ironijom: „Podjednaka krivica? Ne baš. Nacija u centru Klarkovog narativa nije moćna Nemačka već mala, kopnena balkanska država, koja se nedavno oslobodila dominacije Otomanske Turske, (...) To je ta (...) konvencionalno nanovo demonizovana za svoj deo u jugoslovenskim ratovima 90-ih (...) mala Srbija". Džons dalje dovodi u sumnju Klarkova nastojanja da postigne efekat sugerisanjem (kroz akt 1903) kako se radi o poluvarvarskoj gangsterskoj državi, gde oficirski kor (četiri oficira - M. B.), na užas Evrope, demonstrira

\footnotetext{
${ }^{118}$ S. McMeekin, Christopher Clark, "Sleepwalkers: How Europe Went to War in 1914", History Today, December 2012.

${ }^{119} \mathrm{~S}$. Griffith, „History will never be the same again: The Sleepwalkers, by Christopher Clark", Daily Mail, 12 November 2012.
} 
svoj civilizacijski nivo komadanjem nepopularnih monarha, kralja Aleksandra i kraljice Drage, pokoljem kakvog bi se postideli i francuski revolucionari. ${ }^{120}$

Ozbiljnija kritika ovog pretencioznog poduhvata stigla je iz pera američke istoričarke Marije Todorove. ${ }^{121}$ Ona na prvom mestu dovodi u pitanje njegove metodološke postavke. Klark po njoj beži od suštinskog "zašto" (faktora dugog trajanja) kako bi slobodno arbitrirao u pojavnom redosledu i konstrukcijama, te sam uspostavljao uzročnu hijerarhiju. On nastoji da sugeriše čitaocima da činjenice govore za sebe i da je njihovo značenje transparentno. Fokusirao se na lično i moralno (šta god to bilo). Todorovoj nije bilo teško da odmah uoči da je svu složenost zamenio fokusiranjem na Balkan. „Onda je to bio Balkan i brkata Crna ruka, sada Bliski istok i bradata Al-Kaida. Vraćajući natrag Sarajevo sa punom uzročnom težinom (i ne bez aluzije na Srebrenicu, Sarajevo 90-ih, zgražajući ultimatum iz Rambujea 1999. kao opravdanja za nečuveni ultimatum Beča 1914) vodi nas do stare teorije, evropskog bureta baruta'." I ona uočava u takvom nastojanju funkciju njegove drame iz 1903.

Klark minimizira, piše Todorova, suštinu aneksione krize 1908. svodeći je na puku formalnost koja nije suštinski promenila stvari na terenu. Time je zaista udario na celokupnu istoriografsku baštinu, pa i onu konzervativnu koja nije mogla da zaobiđe dalekosežne posledice ove krize po evropske odnose.

Todorova raskrinkava njegove nesuvisle apoteoze AustroUgarskoj koja nasuprot „zaostaloj, neurbanizovanoj, nepismenoj zemlji malog poseda gde dominira oralna kultura, gde nedostaje domaće aristokratije, gde je nazadna ekonomija", predstavlja kosmopolitsku imperiju koja donosi progres i industrijalizaciju. Todorova smatra da Klark ne razume da je srpski nacionalizam u Bosni vezan uz agrarno pitanje i očuvanje feudalnih struktura (uprkos najavljenoj reformi iz polovine XIX veka), dok su njihovi zemljaci u Srbiji, Hrvatskoj i Mađarskoj bili slobodni. Ona takođe uočava tu njegovu potrebu da se neprestano vraća na svoju tezu o "balkanizaciji francusko-ruskih odnosa” (poglavlje Devet) i „balkanskog uzročnog scenarija”. Ta njegova nastojanja „pre

${ }^{120}$ Nigel Jones, "Let's not be beastly to the Germans", The Spectator, 27 September 2012. Pored stručnih komentara ovaj istoričar saradnik BBC i ÖRF (Austrijski radio), urednik BBC History Magazine (2000-2003) upozorava da istoričar australijskog porekla gaji duboku "teutonofiliju”, da ga je nemačka vlada odlikovala Krstom za zasluge.

$121 \mathrm{M}$. Todorova, "Outrages and their outcomes", Times Literar Suplement, 4 January 2013. 
otkrivaju Klarkovu svekoliku antipatiju prema Rusima a simpatije prema Habzburzima".

Dodajmo ovim zapažanjima da je još veća greška što u svojoj teoriji "konspiracije" uporno odbija rezultate klasičnog dela Vladimira Dedijera (koje puno puta navodi) i ne želi da vidi ni kod njega ni kod drugih da jedan autentičan pokret među omladinom nosi i stvara ideju caroubistva, te da oni iniciraju i traže kontakte i podršku. Uporno ljubomorno održava kostrukciju da se radilo o eksportovanoj konspiraciji. Ignoriše eksplicitnu tezu Ištvana Deaka da je praktično još samo zajednička armija održavala na okupu to carstvo posle $1848 .{ }^{122}$ Jedino što Klark "priznaje" jeste da je "teško" da se njegova teza dokaže "jer nema stvarnih pisanih tragova". ${ }^{123}$

Klark, kao i jedan broj drugih istoričara i kritičara koji učestvuju u promovisanju novih knjiga, ne uočavaju, ili ne žele da uoče upozorenja profesora Andreja Mitrovića o neskladu brzih odluka da se ide u rat, pod izgovorom odgovornosti Srbije, i pored izveštaja koji su pristizali iz samog Sarajeva, a potom i od specijalnog delegata Viznera 13. jula. Do tada merodavni organi i sam specijalni delegat Fridrih fon Vizner mogu da konstatuju da atentatori ističu da je ideja njihova, a da su se oni obratili Ciganoviću i Tankosiću samo za pomoć. Vizner telegrafiše "da se osnovano može sumnjati da nacionalni pokret u Bosni i Hercegovini podržavaju neke organizacije iz Srbije koje srpska vlada toleriše, ali da 'nije moguće dokazati učešće srpske vlade u atentatu, u njegovoj pripremi ili u obezbeđivanju oružja' pa čak da za tako što nema mesta ni za sumnju 'pošto postoji mnogo više razloga za tvrdnju da je to isključeno'".124

122 Istvan Deak, Beyond Nationalism: A Social and Political History of the Habsburg Officer Corps, 1848-1918, Oxford University Press, New York, 1990.

123 John Zametica, Book review on Christopher Clark's, Sleepwalkers.

${ }^{124}$ А. Митровић, Србија, стр. 12-13 (prema: ÖUA, Bd 8, str. 436-437). Konrad je uveče 29. juna kad je stigao u Beč već jezgrovito saopštio Bertholdu: "Rat, rat, rat" (prema: H. Hantsch, $n$. d., str. 558). Mitrović ističe tri momenta: prvo da je saglasnost 5 . i 6 . jula postignuta kad istraga nije dala još nikakve rezultate, dakle bez dokaza o odgovornosti službene Srbije, drugo, u razgovorima niko i nije pominjao odgovornost Srbije i treće, o ubistvu Franje Ferdinanda stvarno nije ni posebno raspravljalo niti je koga stvarno zanimalo ko je zaista zamislio atentat (A. Митровић, Н. Д., стр. 17-18). Vilhelm je 30. juna poručio „Sad ili nikad”, a otpravnik austrougarskog poslanstva u Beogradu Štork "iako je dozvoljavao da je atentat u datom trenutku nesaglasan 'koncepcijama rukovodstva Srbije' ipak je najotvorenije predlagao da se Monarhija obračuna sa Srbijom" (isto, str. 17, 19, prema: ÖUA, Bd 8, str. 219 i Die deutchen Dokumente zum Kriegsausbruch, Bd1, Berlin 1922, str. 10-11). 
Posle izloženog, možemo da zaključimo da paralelno postoje težnje da se, na jednoj strani, dograđuje na postojeće i priznate temelje nauke o Prvom svetskom ratu, a na drugoj, da smo svedoci pomodnih shvatanja i tumačenja, koje svesno ili nesvesno vode protagoniste da oživljavaju nekadašnje političke rasprave pod paravanom "naučnog", sada u novim okolnostima kada u nekim sredinama postoji želja da se ukinu "poslednji tragovi nepravednog Versaja" ili da se napišu "kompromisne verzije" koje ne bi proizvodile loša osećanja unutar nove Evrope. Za Istok to ne važi.

\title{
Summary
}

Mile Bjelajac, Ph. D.

\section{New (Old) Controversies on the Origins of WW I on the Eve of $100^{\text {th }}$ Anniversary}

\begin{abstract}
Key words: Origins of WW I, Sarajevo 1914, Serbia, Christopher Clark
\end{abstract}

The discussions and controversies regarding the "war guilt" and the origins of WW I have lasted for almost a century now. They have not been focused on scholarly matters only, but on the ideological and political ones as well. The ideological and political content has had a considerable impact on the scholarly field ever since. In that sense, it has not changed much on the eve of the $100^{\text {th }}$ anniversary.

Germany, and to a lesser extent Austria, showed a particular interest in denying the conclusion of Special Commission of Peace Conference at Versailles that resulted with Treaty article no. 231 (177 in Austrian case). The conservatives among historians did their best to deny the conclusion and win the sympathies of the neutrals. The first step was the deliberate hiding of self- incriminating documents in the archives or excluding (perhaps destroying) a number of critical documents, namely on the discussions at Potsdam on $5^{\text {th }}$ and $6^{\text {th }}$ July 1914, and on the Austrian-Hungarian ultimatum to Serbia. All memoirs 
were carefully censored before publication. Hundreds of books and thousands of articles were distributed all around the world promoting the German view. Special institutions were created for that purpose. Foreign scholars received support and their books were translated. Others, who did not comply with the German view, were severely criticized or obstructed. All these efforts met with some success in the U.S.A.

Later, the Cold War and the undisputed responsibility of Germany for WW II led to a somewhat softer approach in France and Great Britain towards German responsibility for the outbreak of WW I. This approach was welcomed by the conservatives in Germany. Soon, however, the research of the German historian Fritz Fisher and his associates struck a major blow at an old construction. In the words of Volker Berghahn "after many years of dispute among historians about who was responsible for outbreak of war in August 1914 in which German scholars either blamed the Triple Entente for what happened or argued that all powers had simultaneously slithered into the abyss ... Fisher controversy produced a result that is now widely accepted in the international community of experts on the immediate origins of the war - it was the men gathered in Imperial Palace in Berlin who pushed Europe over the brink ... together with 'hawks' in Vienna". But can we really make such a claim? If one examines the works and monographs published in the 1990 s and in the first years of the $21^{\text {st }}$ century, one finds much that confirms the assertion made by Berghahn. On the other hand one will also find very recent accounts that try to negate what was established in the previous decades. The question thus imposes itself: on what grounds? These newly-published works do not offer any new evidence. Rather, they elaborate the pre-1914 political slogans, mixing them up with new trends developed in the wake of the 1990 s Yugoslav crisis. Some scholars loudly claim that they have finally discovered the real culprits of the world tragedy in 1914 - Serbia and Russia. Serbia "near barbaric gangster state" plotted against AustroHungary in pursuing its great national project (Nachertanie, 1844), and was supported by Russia - not the other way around, there were no Austrian plots and plans, no Austrian domestic problems from Poland to Croatia and Bosnia, from Istria to Transylvania. In order to make a "stronger case" these scholars ignore Fischer's findings. Germany is not seen to have played an active role at all. In order to create an alibi for Vienna, or the Ottoman Empire some time before, this breed of historians has turned upside down the historical meaning of the national 
struggles for liberation in Europe in the $19^{\text {th }}$ and $20^{\text {th }}$ centuries. They recreate the myth of the multi-cultural and multi-ethnical prosperous empires that dominated the Balkans at the turn of the century. In other words "civilized" empires are mandated to impose "civilization" on "uncivilized" who commit "outrage" against civilized Europe and the world. A characteristic expression of this view goes like this: "By introducing the unitary nation state as the new organizing concept, the treaty (Berlin, 1878) planted the seeds of future conflict, from the Balkan Wars of 1912-1913 and the First World War to recent civil wars and ethnic cleansing in former Yugoslavia. The magnitude of the defeat ... and territorial loses that followed proved fatal to the project of Muslim liberal reform and modernization that the Ottoman state had launched in the middle of the nineteenth century".

It has to be said that the huge amount of published and archival sources listed in support for "the new" thesis is actually just a decorum in these works. For those who are familiar with the matter it is obvious that the famous classic accounts are misinterpreted or deliberately put aside.

Even though the number of such pretentious works is small, they are "legitimized" by big publishers and the universities where the writers hold their posts. They could certainly mislead the less educated public or students just starting their studies. The approval that such writings have received in the media of some countries makes the current discussion as polarized as it was immediately after the outbreak of WW I. 